\title{
SALT-DOME LOCATIONS IN THE GULF COASTAL PLAIN, SOUTH-CENTRAL UNITED STATES
}

By Jeffery D. Beckman and Alex K. Williamson

U.S. GEOLOGICAL SURVEY

WATER-RESOURCES INVESTIGATIONS REPORT 90-4060

7

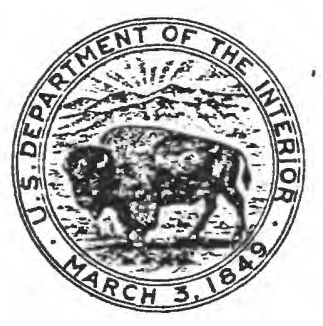

A Contribution of the

Regional Aquifer-Systems Analysis

Program 
DEPARTMENT OF THE INTERIOR

MANUEL LUJAN, JR., Secretary

UNITED STATES GEOLOGICAL SURVEY

Dallas L. Peck, Director

For more information write to:

Project Chief

U.S. Geological Survey Gulf Coast RASA

N. Shore Plaza Bldg., Rm. 104

$55 \mathrm{~N}$. Interregional Hwy.

Austin, Texas 78702
Copies of this report can be purchased from:

U.S. Geological Survey Books and Open-File Reports Section Box 25425, Federal Center

Denver, CO 80225-5425 


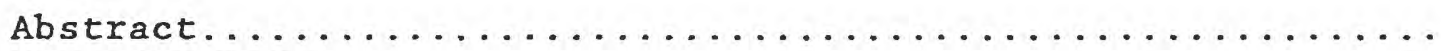

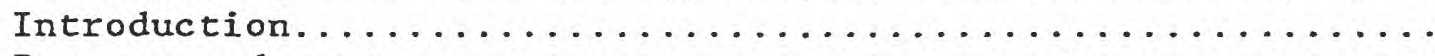

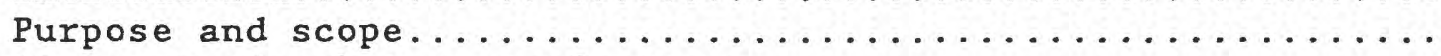

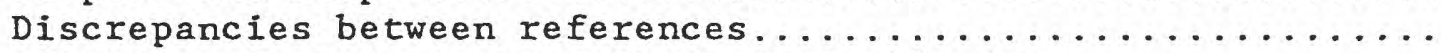

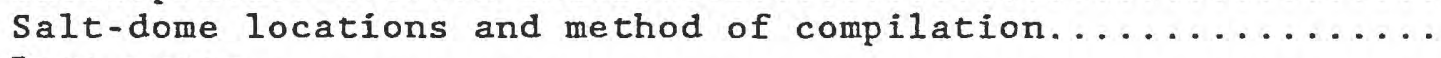

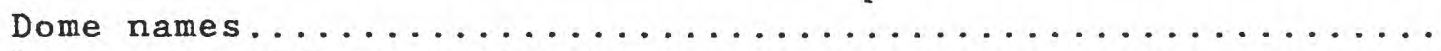

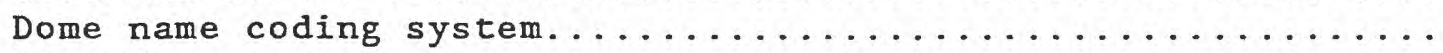

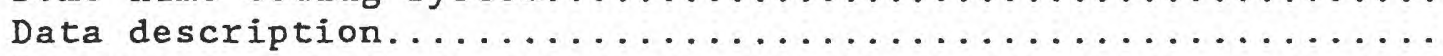

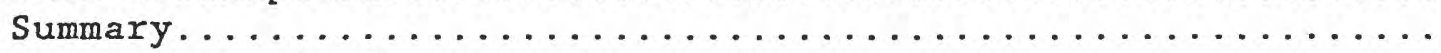

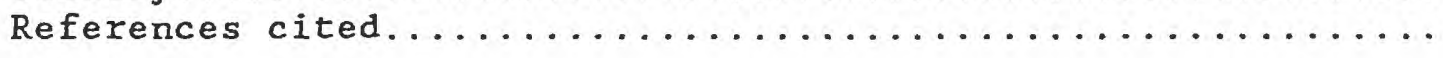

\section{ILLUSTRATIONS}

Plate 1. Salt-dome locations in the Gulf of Mexico Coastal Plain, south-central United States and the adjacent Continental Shelf

In pocket

Figure 1. Gulf Coast Regional Aquifer-System Analysis study area boundary and location of salt basins.......

2-11. Maps showing location of salt domes that penetrate the base of layers:

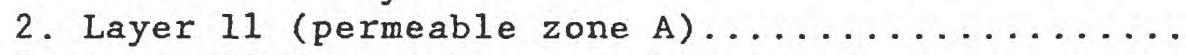

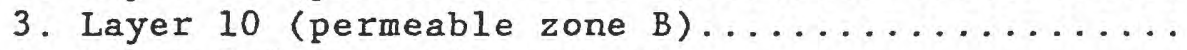

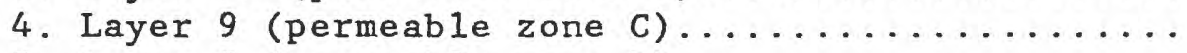

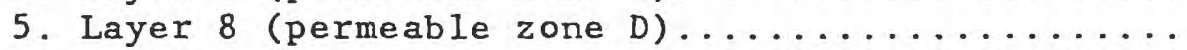

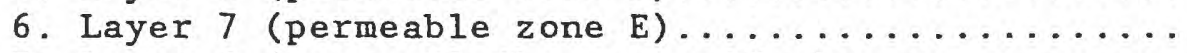

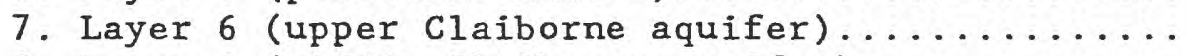

8. Layer 5 (middle Claiborne aquifer)............

9. Layer 4 (lower Claiborne-upper Wilcox aquifer)..

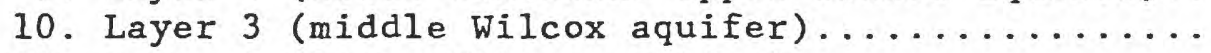

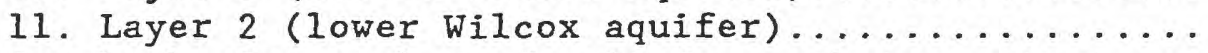

12. Graph showing number of salt domes that penetrate

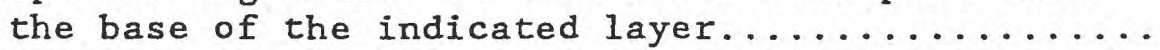

13. Graph showing total number of salt domes and number

of domes where depth to top is unknown, or is

above or below top of Midway confining unit by

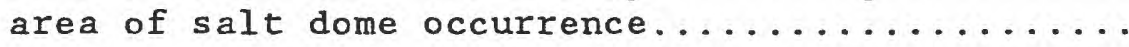




\section{TABLES}

[Table 2 at back of report]

Page

Table 1. Comparison of sources used for locating domes and number of matches between each pair of sources...

Table 2. Map code, salt-dome name, location, depth to salt and caprock, diameter and volume of salt domes,

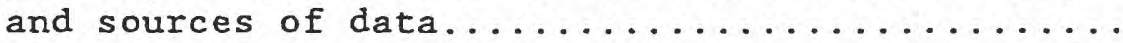

CONVERSION FACTORS AND ABBREVIATIONS

"Inch-pound" units of measure used in this report may be converted to metric (International System) units by using the following factors.

Multiply inch-pound units

foot (ft)

mile (mi)

cubic mile $\left(\mathrm{mi}^{3}\right)$

square mile $\left(\mathrm{mi}^{2}\right)$
By

0.3048

1.609

4.168

2.590
To obtain metric unit

meter (m)

kilometer $(\mathrm{km})$ cubic kilometer $\left(\mathrm{km}^{3}\right)$ square kilometer $\left(\mathrm{km}^{2}\right)$

\section{ALTITUDE DATUM}

Sea level: In this report, "sea level" refers to the National Geodetic Vertical Datum of 1929 (NGVD of 1929)--a geodetic datum derived from a general adjustment of the first-order level nets of both the United States and Canada, formerly called Sea Level Datum of 1929. 


\title{
SALT-DOME LOCATIONS IN THE GULF COASTAL PLAIN, SOUTH-CENTRAL UNITED STATES
}

By

Jeffery D. Beckman and Alex K. Williamson

\begin{abstract}
Information on salt domes in the Gulf of Mexico Coastal Plain. south-central United States and the adjacent Continental Shelf were compiled from major published sources, 1973-84. The location of 624 salt domes is shown on a map at a scale of 1:1,500,000. A color coding system was used to show that the occurrence, size, shape, and location of these domes varies among sources. Two tables of additional data accompany the map and include other available information such as: identifying sources, depth to salt and caprock, diameter, volume, name, and uppermost zone of surrounding sediment that is penetrated, as well as the number of matches between sources. - The locations of salt domes that penetrate specific permeable zones within the gulf coast regional aquifer systems are shown on maps.
\end{abstract}

\section{INTRODUCTION}

The Gulf Coast Regional Aquifer-System Analysis (RASA) covers an area of 230,000 square miles onshore and 60,000 square miles of the adjacent Continental Shelf (fig. 1) (Grubb, 1987). The aquifer system consists of Cenozoic sediments that were divided into aquifers, permeable zones, and confining units (Grubb, 1987, p. 104). This division was accomplished by: 1) Identifying areally extensive units of low permeability; 2) identifying large hydraulic conductivity contrasts between adjacent permeable zones not separated by a regional confining unit; and 3) identifying variations in hydraulic head with depth (Weiss and Williamson, 1985; Weiss, 1990; and Hosman and Weiss, 1988).

Manuscript approved for publication April 12, 1990 


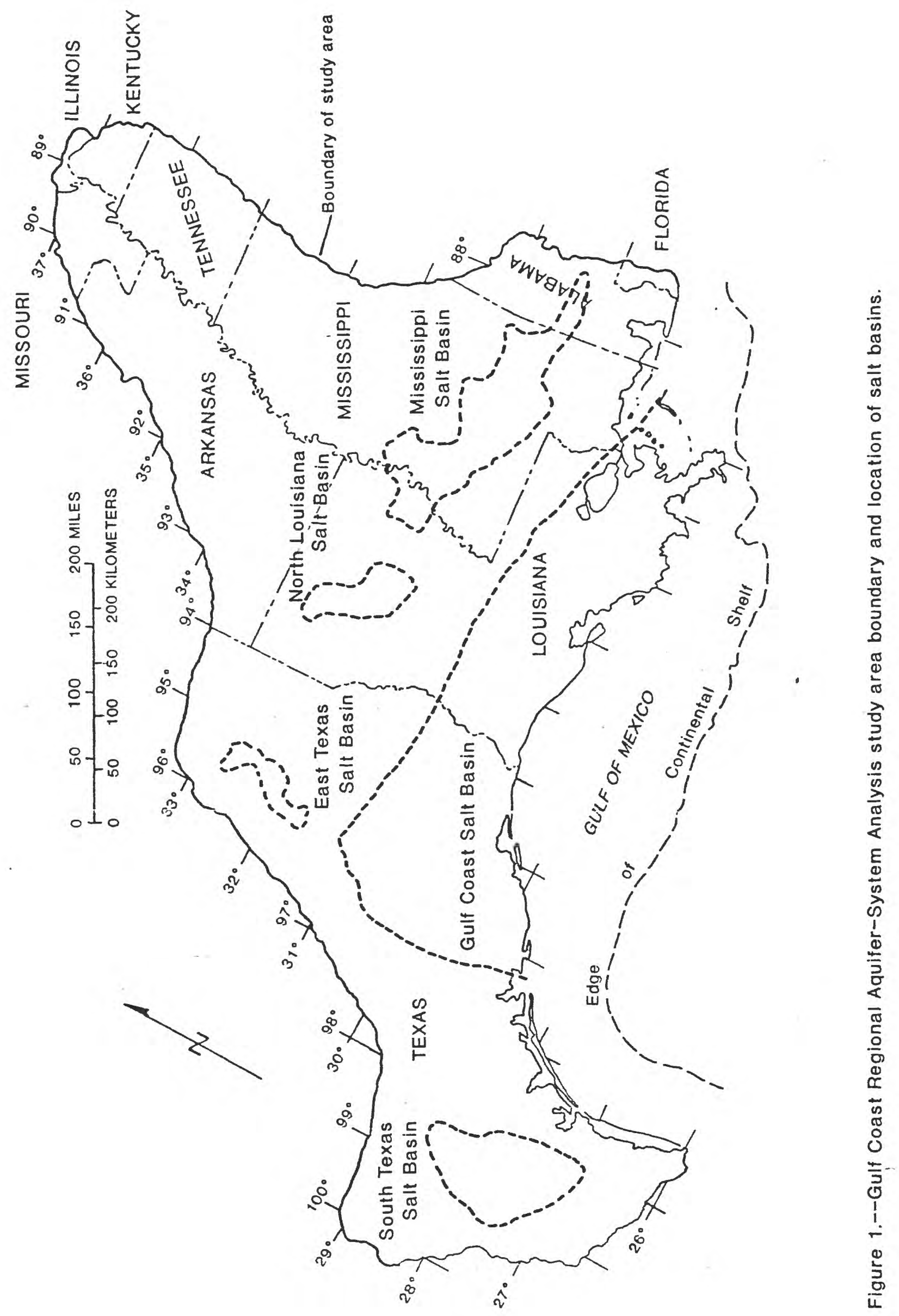


The regional aquifers, permeable zones, and confining units were assigned layer numbers and are, from youngest to oldest:

Layer number

$\begin{array}{cc}\text { Aquifer or } & \text { Confining } \\ \text { Permeable zone } & \text { unit }\end{array}$

Mississippi River Valley alluvial aquifer and permeable zone A (Holocene-upper Pleistocene deposits)

11

permeable zone B (lower Pleistocene-upper Pliocene deposits)

permeable zone $\mathrm{C}$ (lower Pliocene-upper Miocene deposits) zone $\mathrm{D}$ confining unit

permeable zone $\mathrm{D}$ (middle Miocene deposits) zone $\mathrm{E}$ confining unit

permeable zone E (lower Miocene-upper Oligocene deposits) Vicksburg-Jackson confining unit

upper Claiborne aquifer middle Claiborne confining unit

middle Claiborne aquifer lower Claiborne confining unit lower Claiborne-upper Wilcox aquifer middle Wilcox aquifer lower Wilcox aquifer Midway confining unit

The layer numbers shown above will be used throughout the rest of this report for convenience. The Midway confining unit is the base of the flow system throughout much of the study area (Grubb, 1984).

Salt domes in the study area are found in five distinct regions. These regions, known as salt basins, probably reflect thick accumulations of sedimentary salt. Overburden pressures and density differences created by later sedimentary deposits then caused the salt to flow into salt structures. The salt basins (fig. 1) are: South Texas, East Texas, North Louisiana, Mississippi, and Gulf Coast. The Gulf Coast salt basin, the largest, underlies southeastern Texas, southern Louisiana, and the adjacent Continental Shelf.

\section{PURPOSE AND SCOPE}

This study was initiated under the Gulf Coast Regional Aquifer-System Analysis to compile published data on salt domes to the edge of the Continental Shelf. The composite data were compiled to study the possibility of salt domes as a source of salt in brine waters in Cenozoic sediments of the Gulf of Mexico Coastal Plain in the south-central United States and adjacent Continental Shelf (Williamson and others, 1990, p. 107). The shallowest permeable zone penetrated by each dome has been identified in order to assess the possibility of salt dissolution and movement through the permeable zones. In this report, the compiled data are displayed on a map and in a table. Salt-dome locations and geometry were compiled from eight sources, each of which investigated all or part of the study area. Salt-dome name, location, depth to salt and caprock, diameter, volume, and identifying sources used for this compilation are provided in a table. 


\section{DISCREPANCIES BETWEEN REFERENCES}

Identification of salt dome locations from each of the references used to construct plate 1 are compared in table 1. The discrepancies in dome identification between references are due to several factors. First, the more recent references reflect advances made in seismic surveying and other remote sensing methods of geophysics. Therefore, some structures that were identified by earlier references as salt domes have been reclassified as non-salt structures, whereas other salt domes have been identified for the first time. For this reason, recent references were favored in compiling these data. Second, despite the advancements, identification of salt domes from seismic surveys remains highly subjective (such that two people using the same data may reach different conclusions). Third, the different investigations are based on different databases of raw material and published information. For example, the U.S. Department of the Interior (1983) lists neither Martin (1980) nor Halbouty (1979) as references. Halbouty (1979) lists only those salt domes that have been confirmed by drilling, so that his base list of 343 domes should be considered fundamental. However, Halbouty (1979) also identifies some domes that no other sources identified (for example, Eugene Island Block 231). Finally, the references use different depth criteria for identifying salt domes from deeper salt structures.

Understanding the problem of locating and identifying salt domes from seismic survey data is important because seismic surveys are a major source of information for most of the references used in this report. For example, most of the offshore domes from Martin (1980) were identified from single-channel seismic surveys and gravity surveys. Single-channel seismic analysis does not allow for the differentiation between salt domes and shale plugs (Martin, 1980) because both are piercement structures of similar densities. This may explain the large number of structures (481) that Martin (1980) identified. Additionally, the actual location of salt domes may be blurred because of an effect called sideswipe that allows structures some distance from the map trace of the seismic line to be projected onto the line. Exact salt dome locations can be determined only from a very tight pattern of seismic lines and by correlating seismic surveys with other data.

\section{SALT-DOME LOCATIONS AND METHOD OF COMPILATION}

The salt-dome location map (plate 1) was compiled from eight recently published sources: Anderson and others, 1973; New Orleans and Lafayette Geological Societies, 1973; Halbouty, 1979; Martin, 1980; Louisiana Geological Survey, 1981a and 1981b; U.S. Department of the Interior, 1983; and Jackson and Seni, 1984. Four of these references display both size and location of the salt domes by giving their outlines at various depths: New Orleans and Lafayette Geological Societies (1973) at 10,000 feet; Martin (1980) from 5,000 to 8,500 feet (the depth range representative of one second of two-way travel time on a seismic survey, where the depth depends on the nature of the sediment overlying the dome); U.S. Department of the Interior (1983) at an unspecified depth; and Jackson and Seni (1984) at 10,000 feet.

Four sources aided in locating the salt domes although they did not show their shape. Anderson and others (1973) shows only dome locations. The other three sources (Halbouty, 1979; and Louisiana Geological Survey, $1981 \mathrm{la}$ and 1981b) show the location of salt domes not related to hydrocarbon production and the location and size of oil and gas fields that have a spatial association with possible salt domes. Halbouty (1979) 
Table 1.--Comparison of sources used for locating domes and number of matches between each pair of sources

[The total number of possible salt domes in the study area is 624.]

\begin{tabular}{|c|c|c|c|c|c|c|c|c|c|}
\hline Source & $\mathrm{A}^{*}$ & $M *$ & I* & $J *$ & $\mathrm{N*}$ & $\mathrm{H}$ & $\mathrm{h}$ & $L^{*}$ & $1 *$ \\
\hline A* & 254 & 171 & 108 & 18 & 9 & 168 & 79 & 88 & 26 \\
\hline$M *$ & & 481 & 301 & 8 & 132 & 201 & 54 & 249 & 48 \\
\hline I* & & & 355 & 0 & 126 & 166 & 18 & 218 & 42 \\
\hline $\mathrm{J} *$ & & & & 20 & 0 & 11 & 7 & 0 & 0 \\
\hline $\mathrm{N*}$ & & & & & 133 & 68 & 13 & 90 & 34 \\
\hline $\mathrm{H}$ & & & & & & 241 & $1^{* t}$ & 146 & 4 \\
\hline $\mathrm{h}$ & & & & & & & 102 & 6 & 36 \\
\hline$L *$ & & & & & & & & 300 & 4 \\
\hline $1 *$ & & & & & & & & & 81 \\
\hline
\end{tabular}

- Source covers only a part of the study area.

A* Anderson, and others (1973) covers only onshore and coastal areas.

M* Martin (1980) covers areas south of 32 degrees latitude and east of 100 degrees longltude.

I* U.S. Department of Interior (1983) covers areas south of 30.5 degrees latitude and east of 98 degrees longltude.

J* Jackson and Seni (1984) covers only east Texas salt basin.

N* New Orleans and Lafayette Geologlcal Socleties (1973) covers only offshore and coastal Loulsiana.

H Halbouty (1979) covers 211 areas, salt domes assoclated with oll and gas flelds.

h Halbouty (1979) covers all areas, salt domes not associated with oll and gas flelds.

L* Loulsiana Geolog Ical Survey (1981a, 1981b) covers offshore and onshore Loulsiana, respectively; salt domes that may be related to oll and gas fields.

1* Loulsiana Geological Survey (1981a, 1981b) covers offshore and onshore Loulsiana, repectively: salt domes not related to 011 and gas flelds.

** Halbouty labels one area with two dome names, whlle all other sources show this location as one dome. 
lists only those fields where the presence of salt has been confirmed by drilling. Oil and gas fields displayed on the Louisiana Geological Survey (1981a and 1981b) references were used only to augment the other six sources. Fields located above and around the perimeter of structures that were presumed domes adds validity to the other sources.

The importance of maintaining consistency between references while plotting dome locations on plate 1 required that the salt domes be split into two groups, offshore and onshore domes. Offshore domes were located by aligning latitude and longitude lines because the references disagree on the exact location of offshore area boundaries. The offshore area boundaries for this map were taken from the U.S. Department of the Interior (1983). Onshore domes were located by aligning county and parish boundaries because all sources did not have latitude and longitude lines, and those that did have lines did not agree on their exact location in reference to county and parish boundaries. Although map projections and scales varied among and within reference maps, a good fit was achieved through repeated registration across the map and the use of a variable-scale copying machine.

The locations of salt domes that penetrate the base of individual layers (aquifers and permeable zones) are posted at the approximate center of the dome structure in figures 2-11. The number of salt domes that penetrate the base of each layer ranges from a high of 154 for layer 9 (lower Pliocene-upper Miocene deposits) to a low of 29 for layer 6, the upper Claiborne aquifer (fig. 12). Younger layers generally extend farther downdip (gulfward), which explains how a younger layer can be penetrated by more domes than an older layer.

The distribution of salt domes among the salt-dome basins is quite variable (fig. 13). The percentage of domes within each basin with known depths and penetrating into the gulf coast aquifers (above the top of the Midway confining unit) also varies widely. About 44 percent of the domes have unknown depth and 44 percent penetrate the top of the Midway confining unit, whereas only in 12 percent of the domes is the top of salt deeper than the top of the Midway. The Midway confining unit was chosen to differentiate depths because it is an areally extensive, massive marine clay. Above it are the gulf coast aquifers (Grubb, 1984) and below it are Cretaceous sediments. The depths of most of the offshore salt domes are unknown (fig. 13).

\section{DOME NAMES}

Onshore domes are identified by the salt basin in which they are found and their individual names. Offshore domes generally are identified by the name of the offshore area and the block number of the discovery well for the associated oil or gas field. This leads to some confusion in the naming system of offshore domes since some domes do not trap hydrocarbons and so are named for the dome location. Also, some offshore domes cover a portion of several blocks or are associated with several different oil fields. Some domal features were combined if they were named together in one of the sources. Some were split if one of the sources gave two different names.

Some domes lack a published name; these domes are identified on the map by their identifying code being printed in red (plate 1). Dome name coding system is described in the next section. Onshore domes have been given a name for the county or parish in which they are located and a sequential number. Domes in coastal areas, within State waters, are named for the nearest county or parish and a sequential number. Offshore domes have been given a name for their offshore area and the block number in which most of the dome is located. 


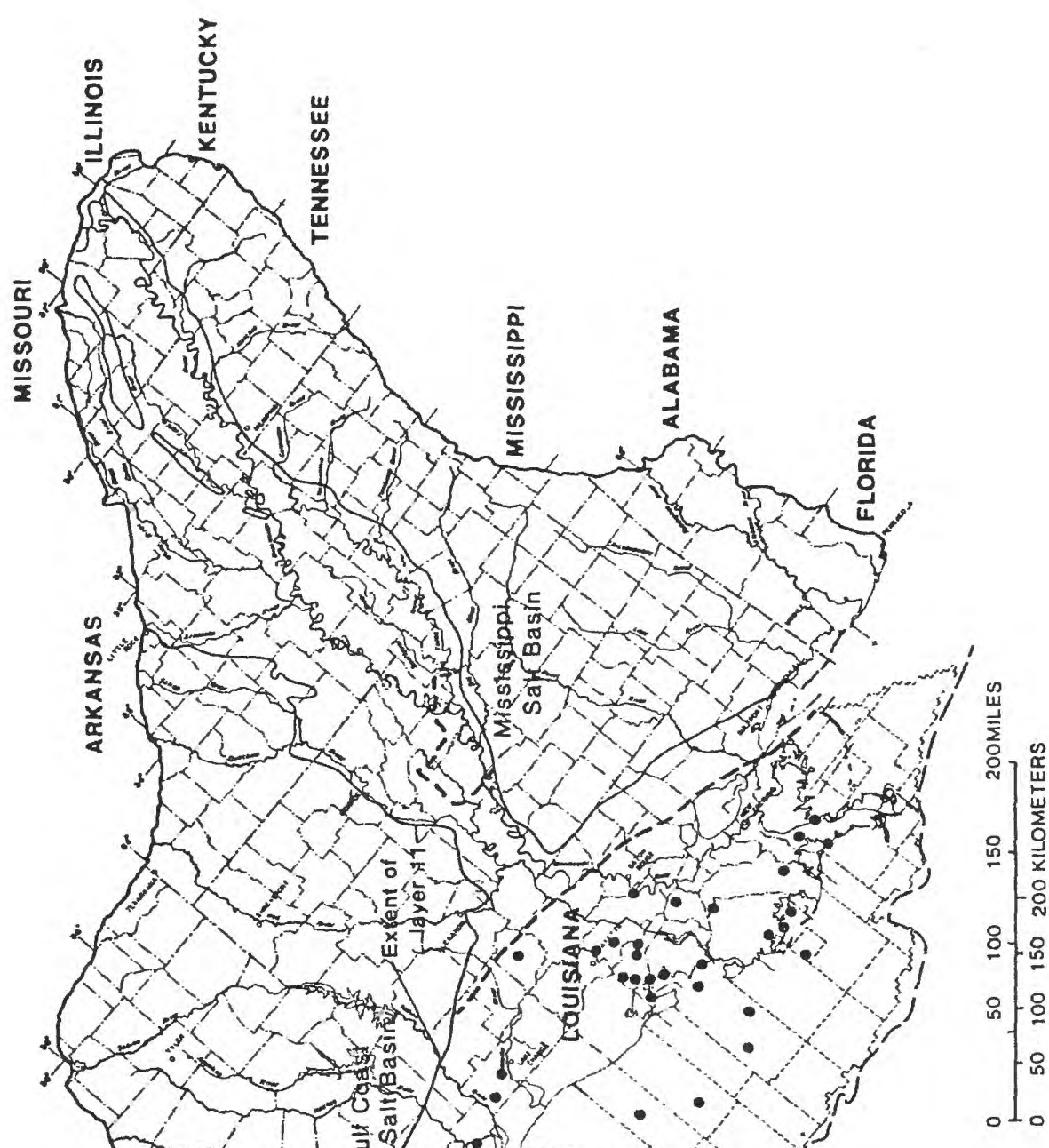

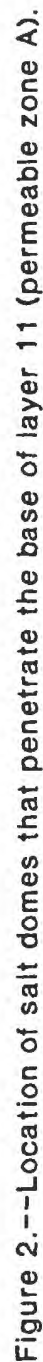




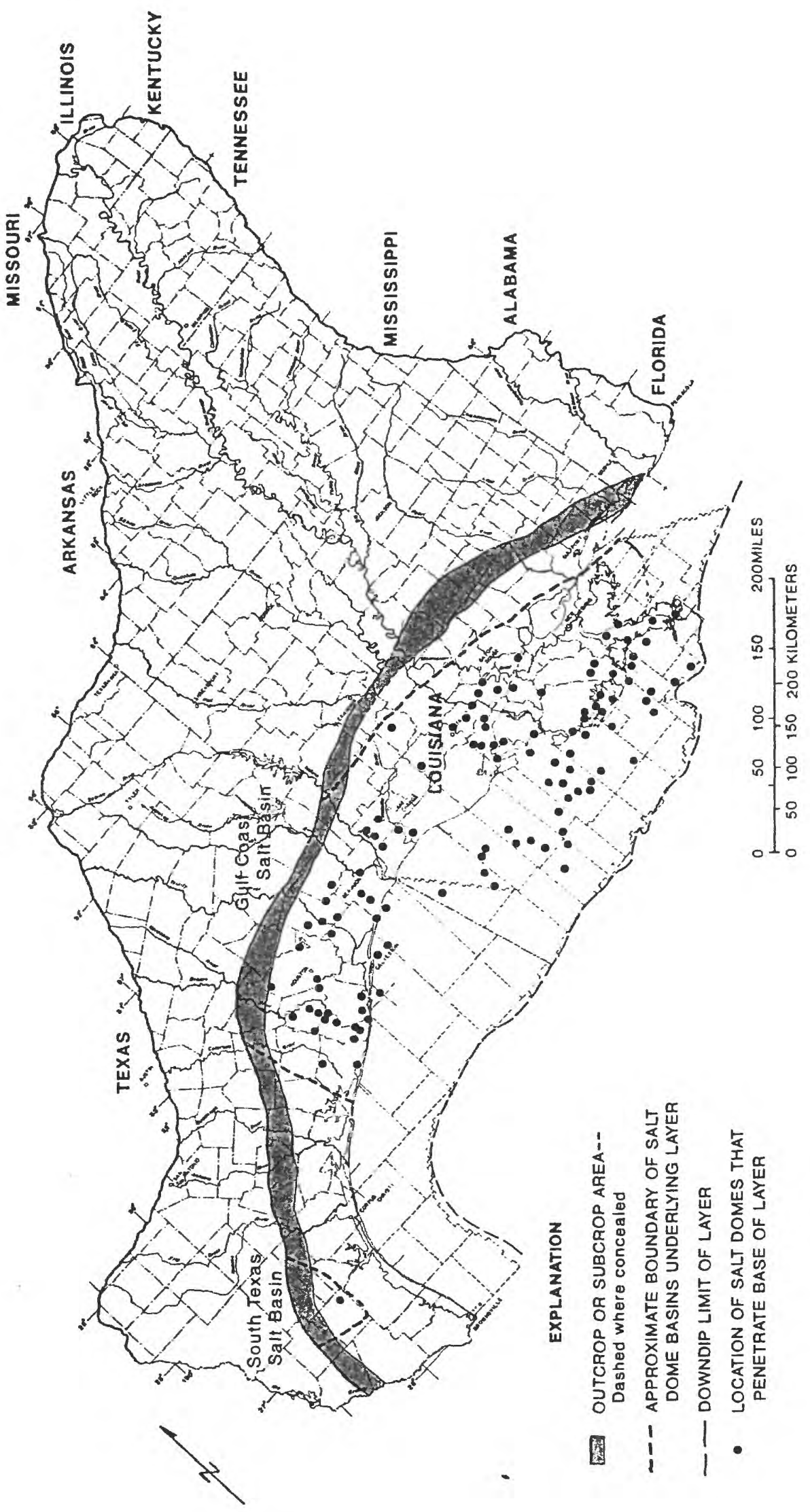

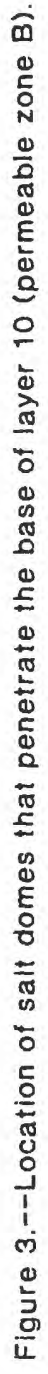




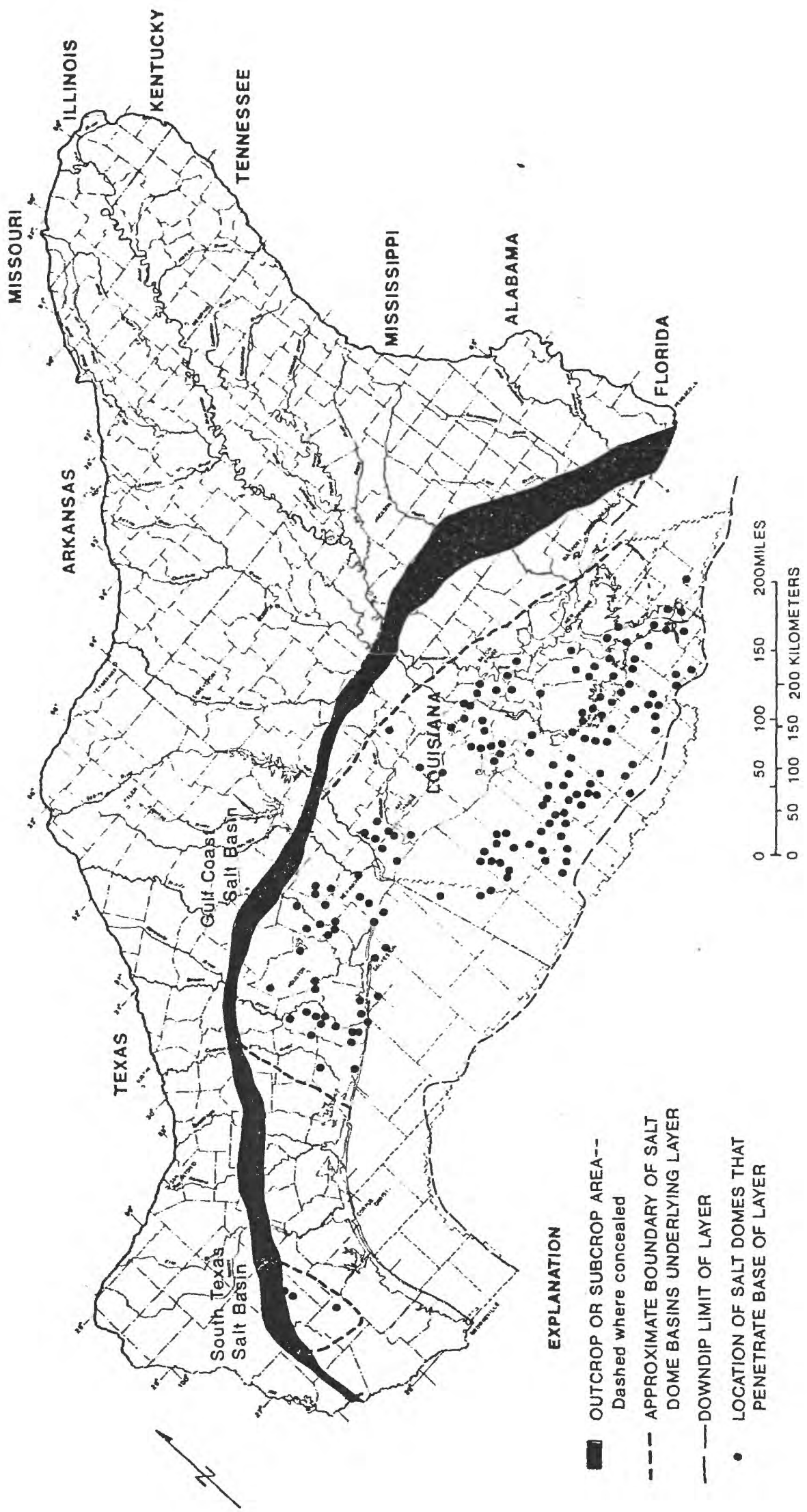

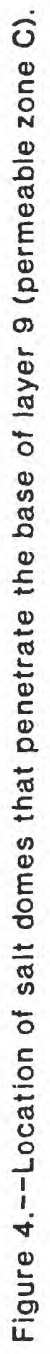




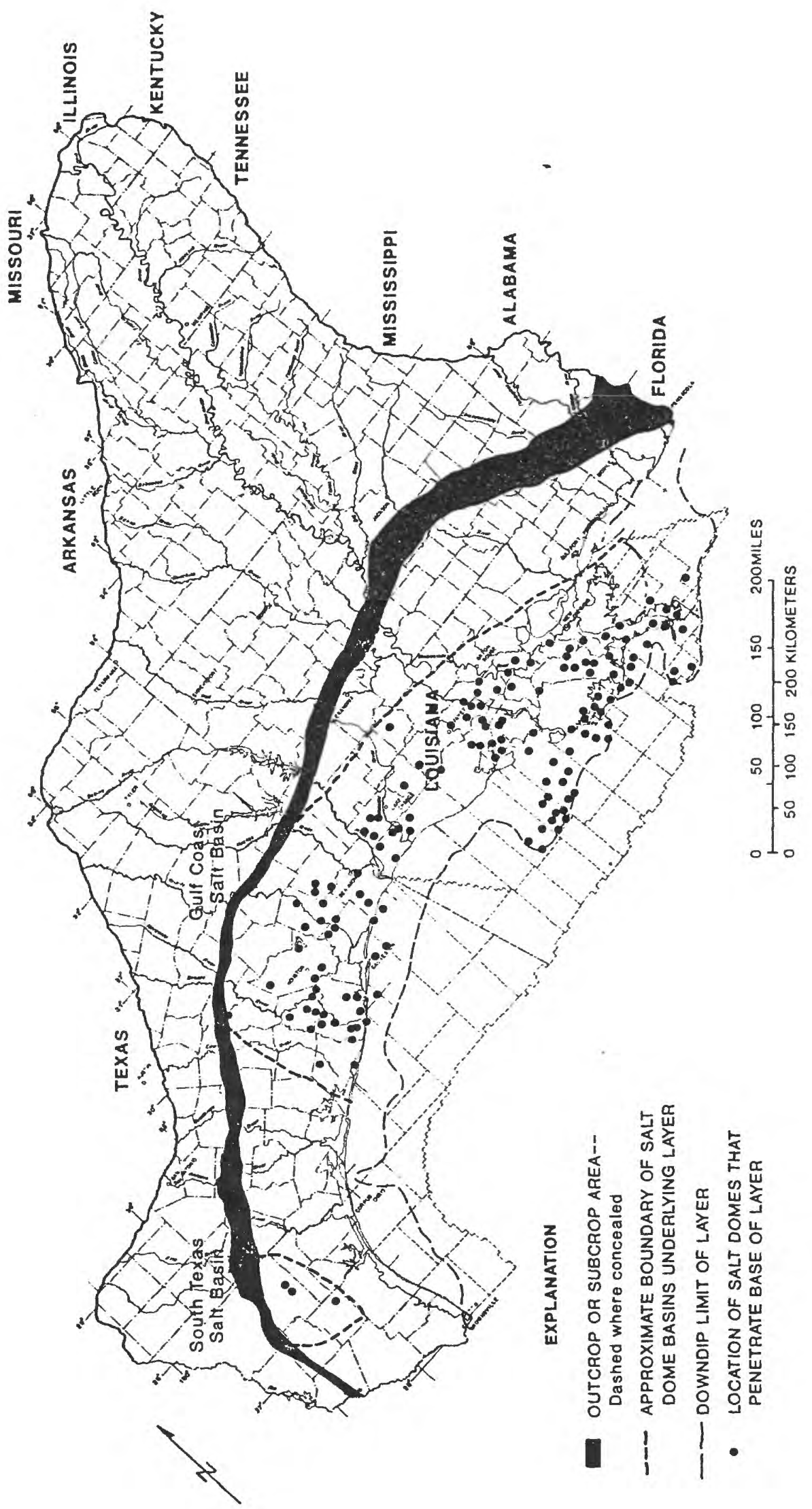

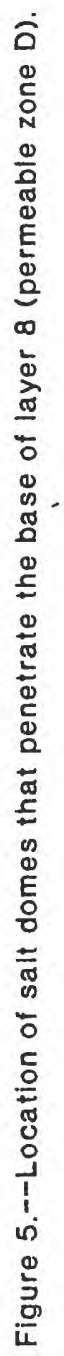




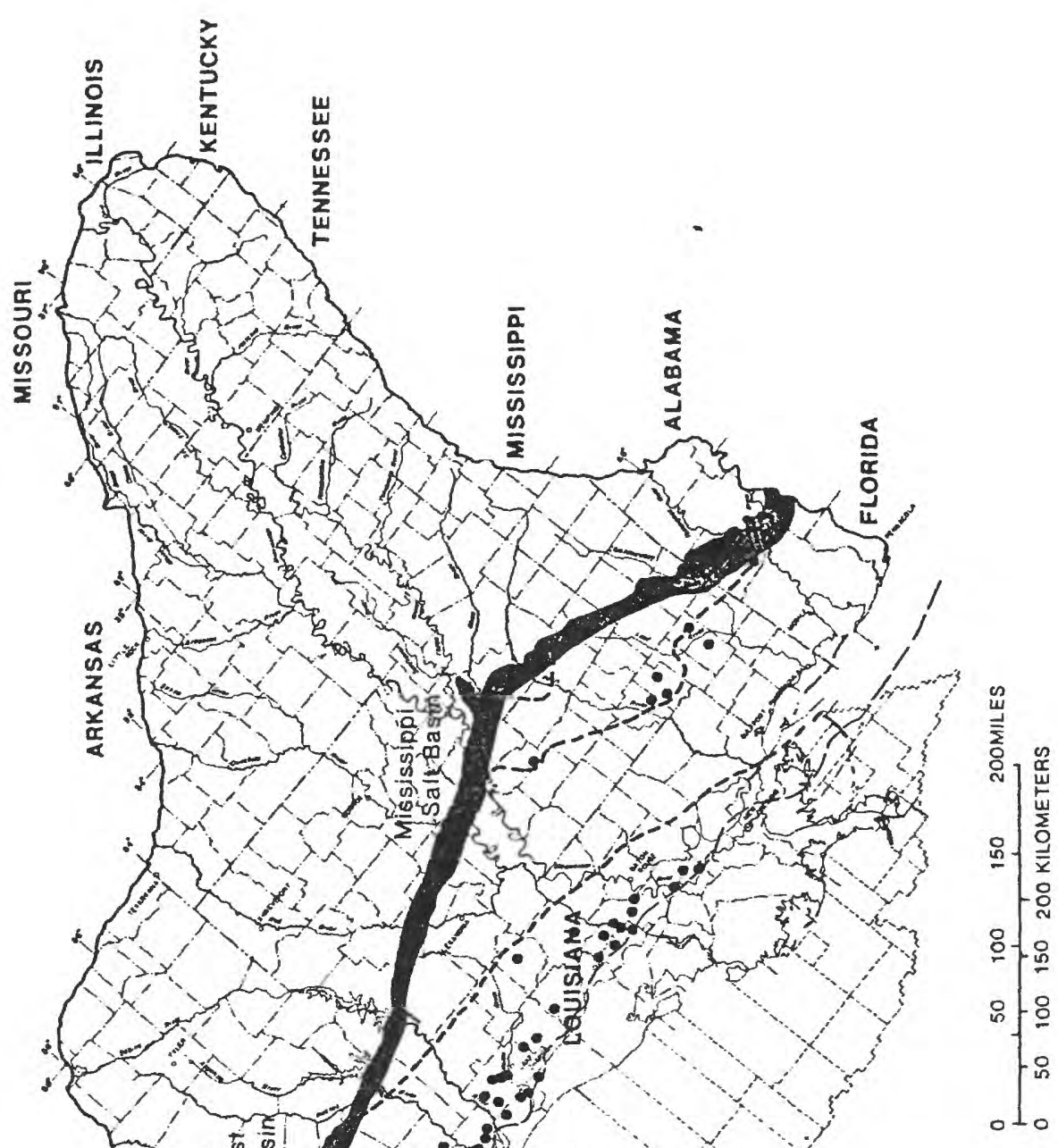

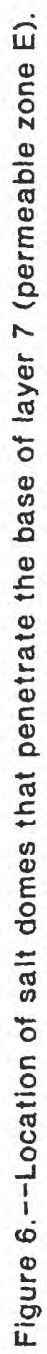




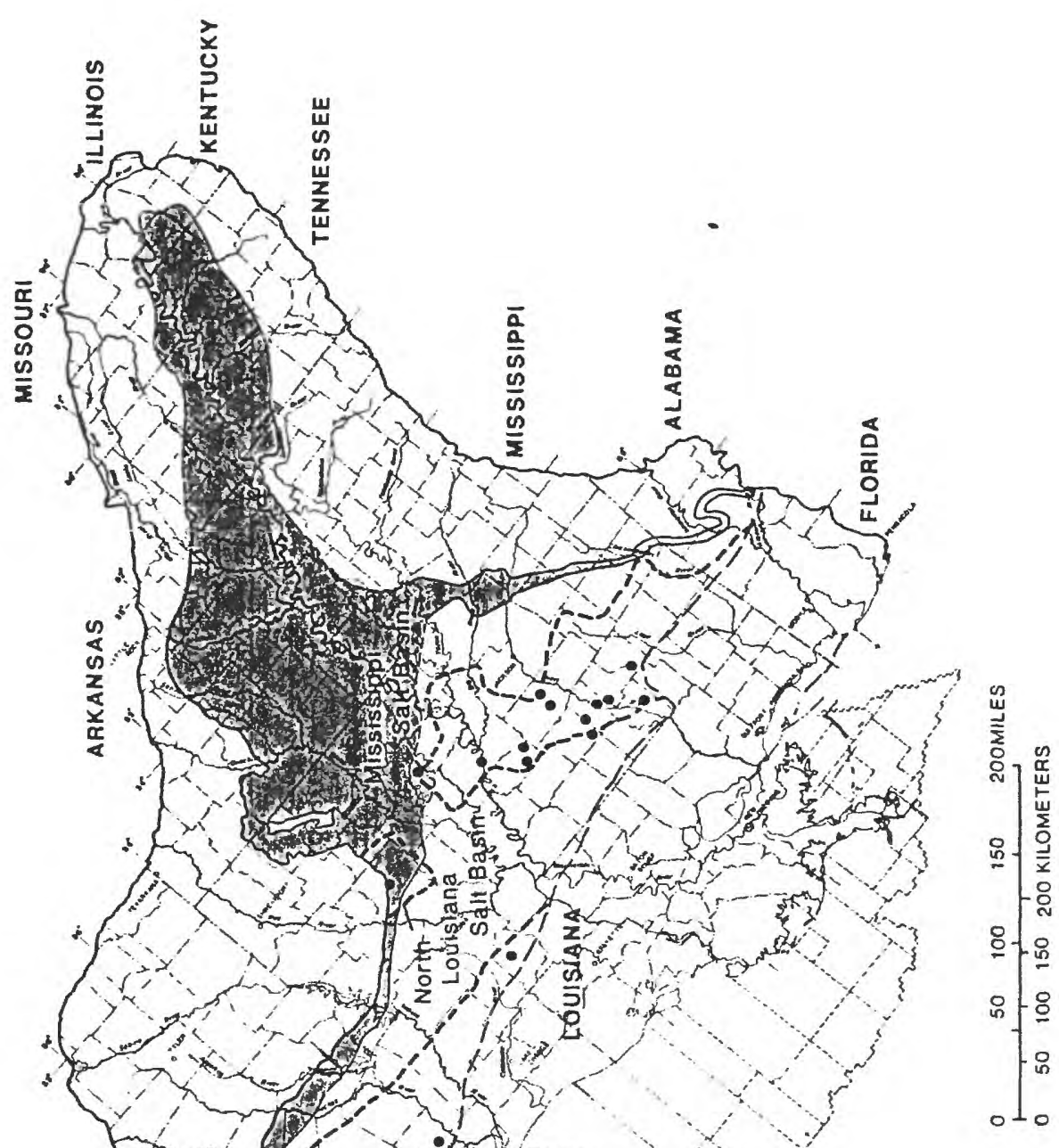

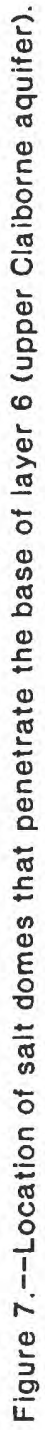




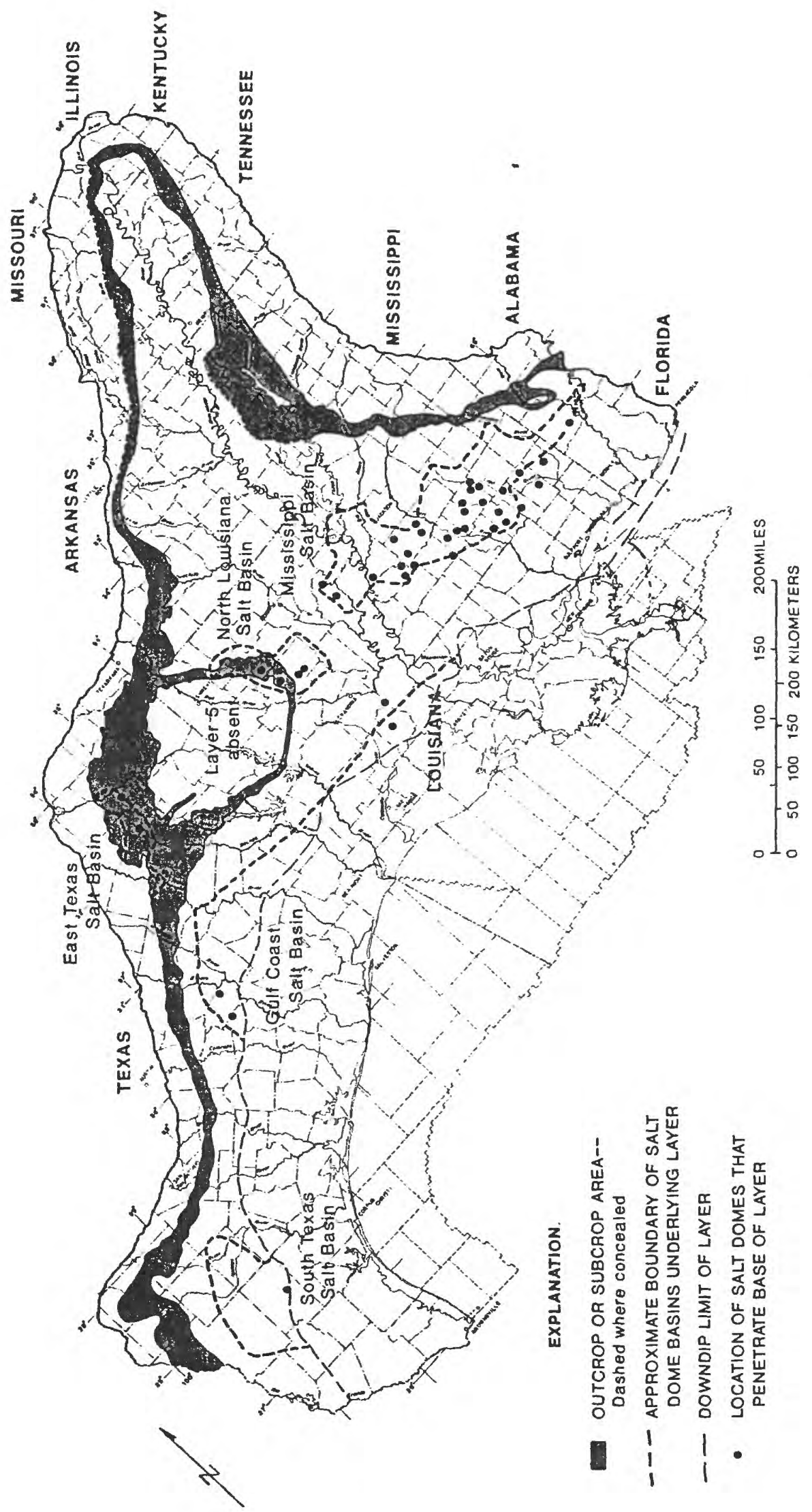

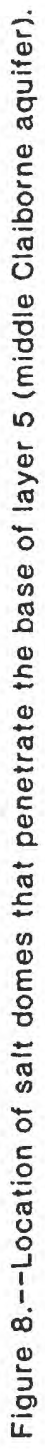




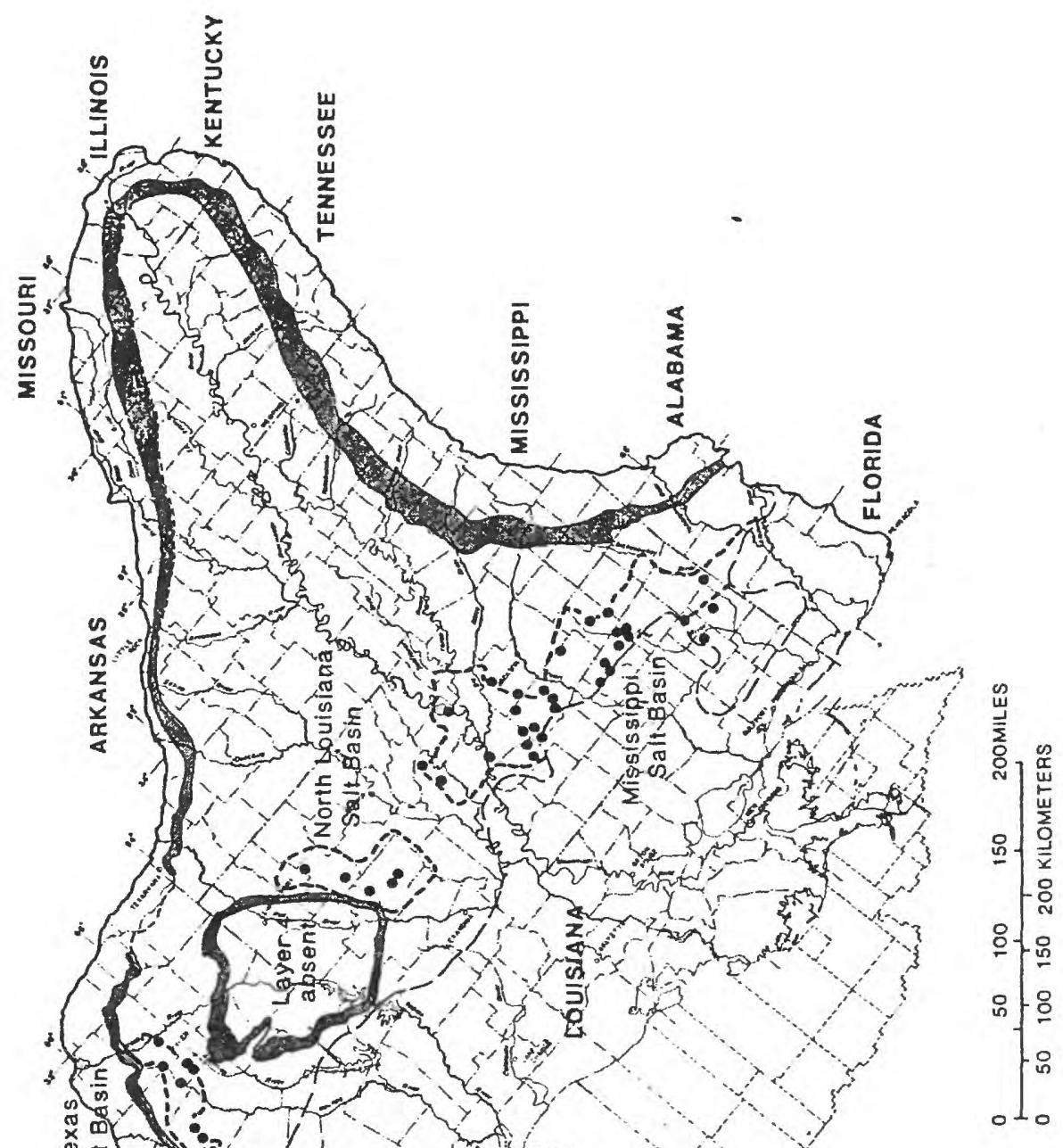

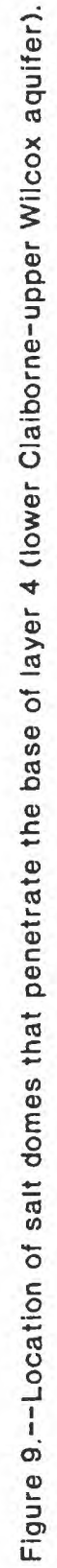




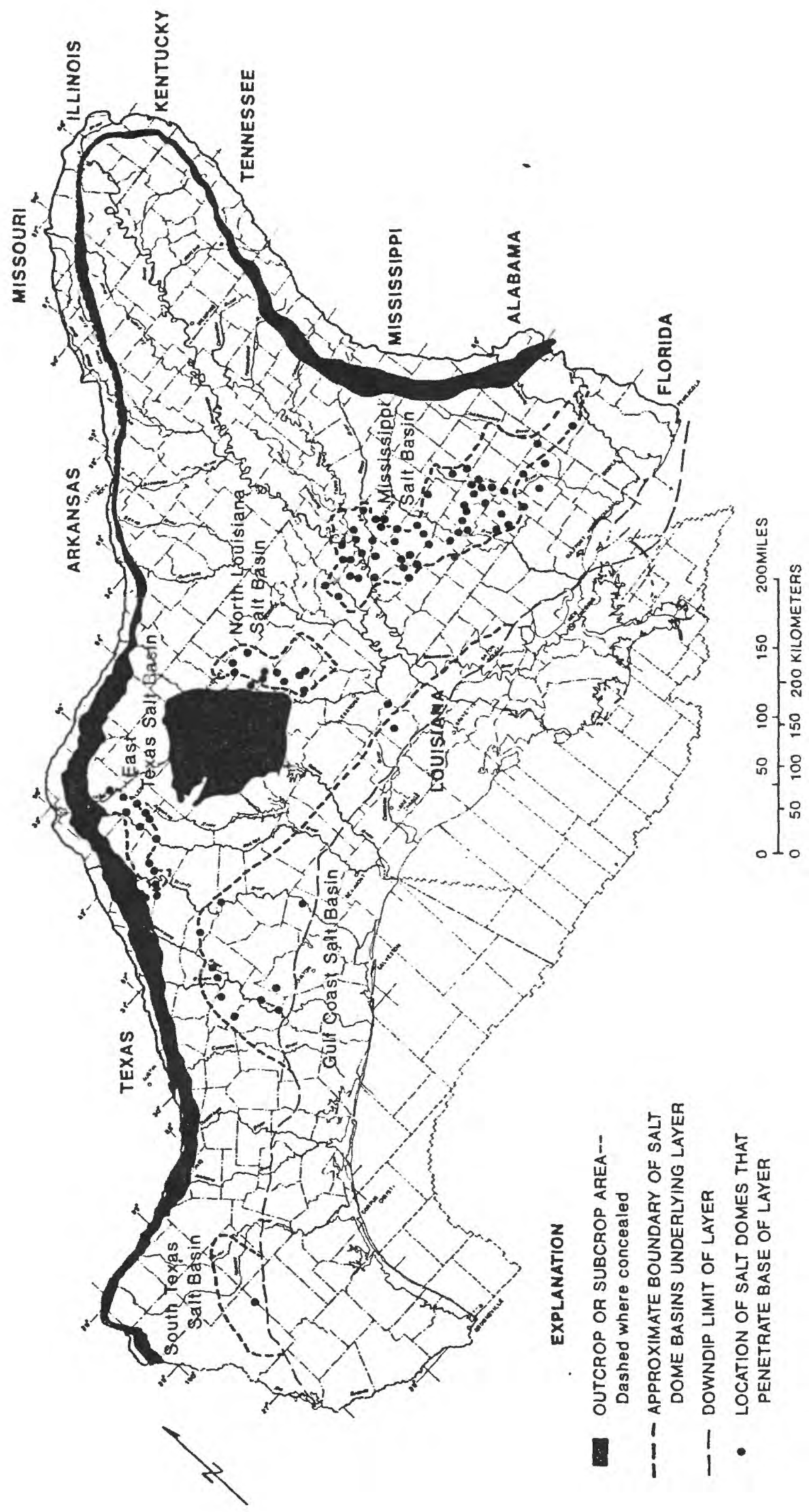

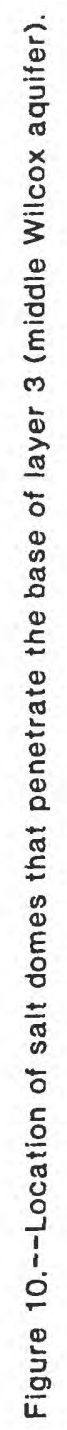




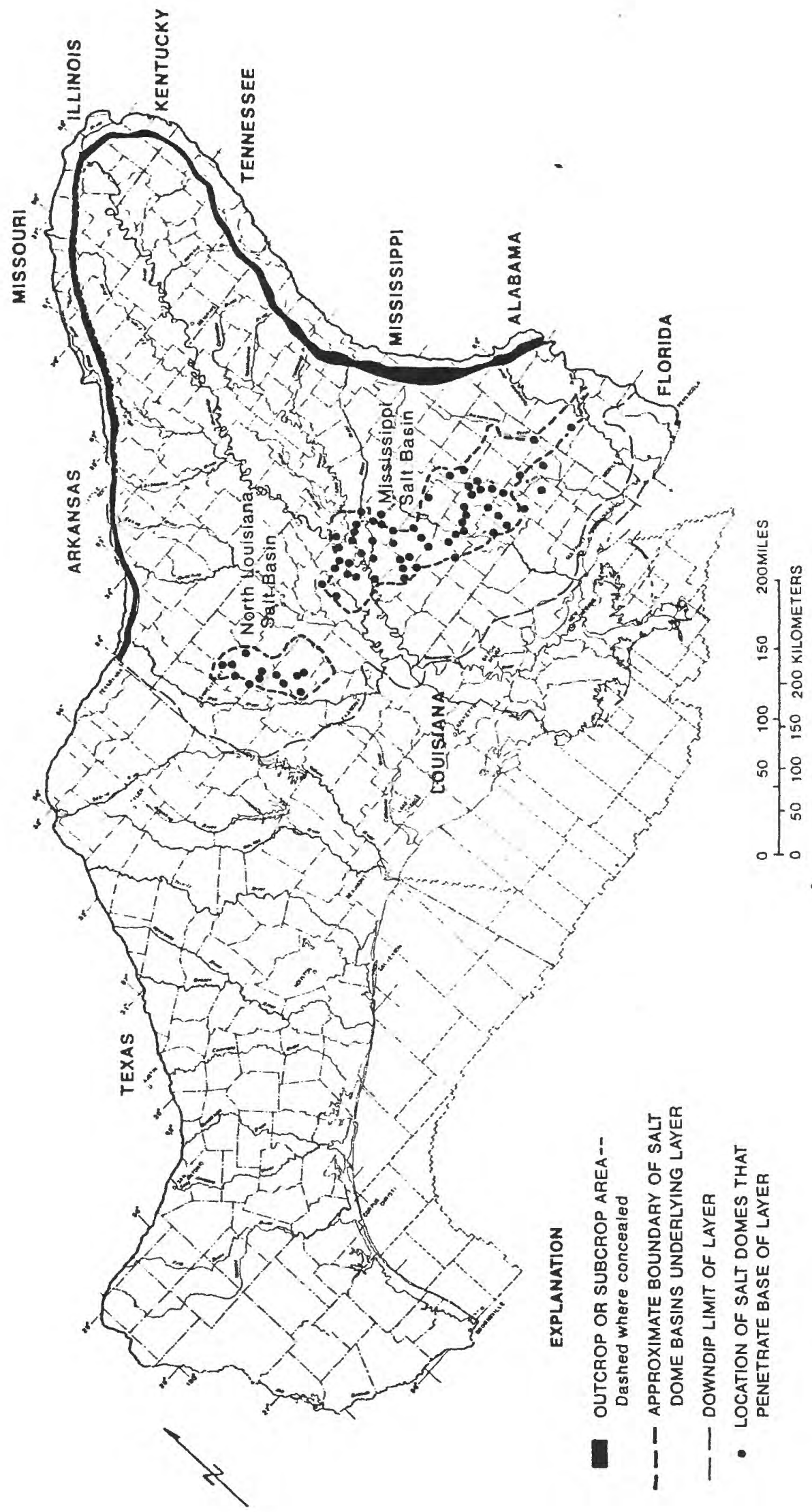

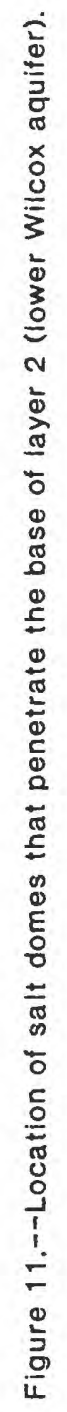




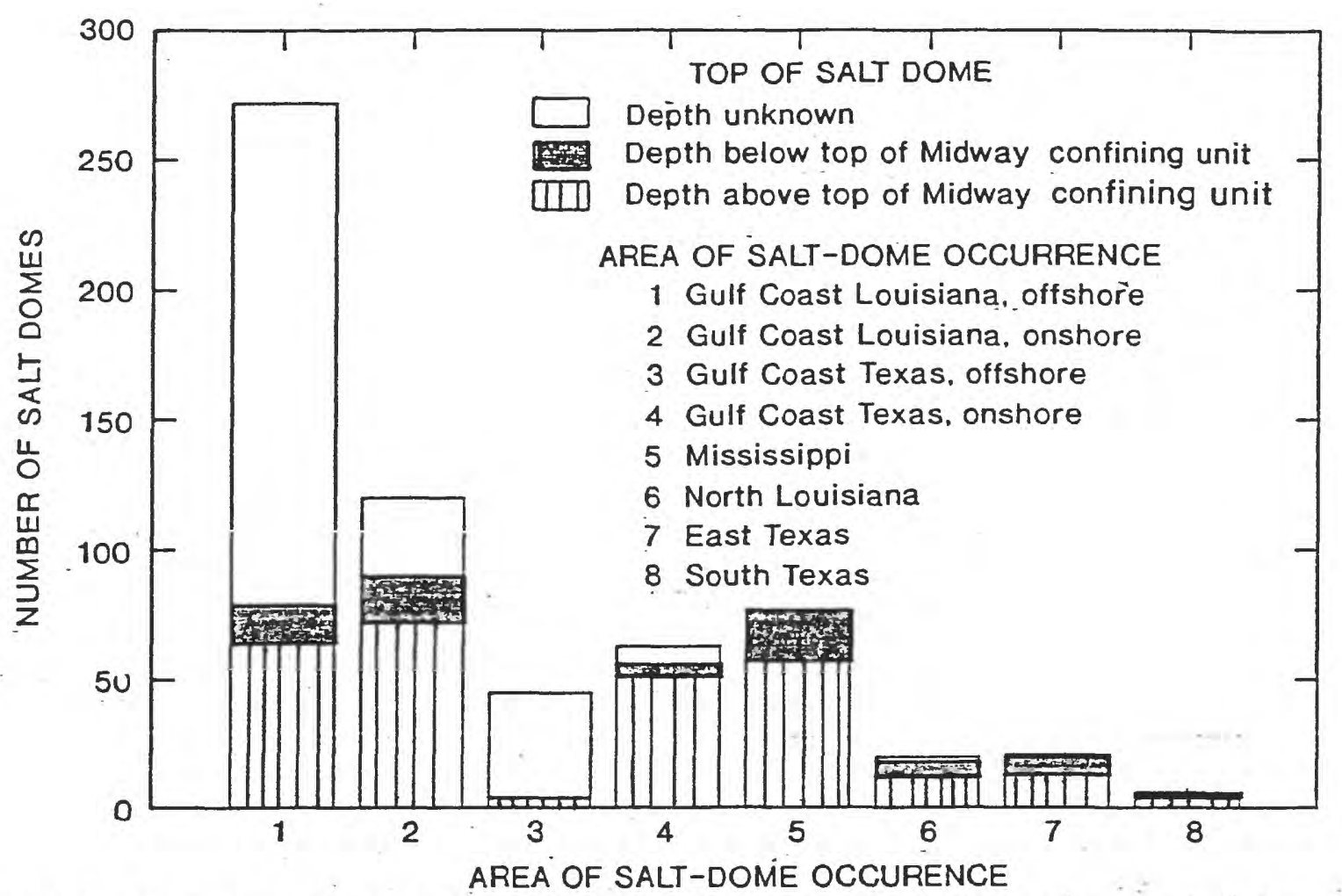

Figure 13.--Total number of salt somes and number of domes where depth to top is unknown or is above or below top of Midway confining unit by area of salt-dome occurrénce.

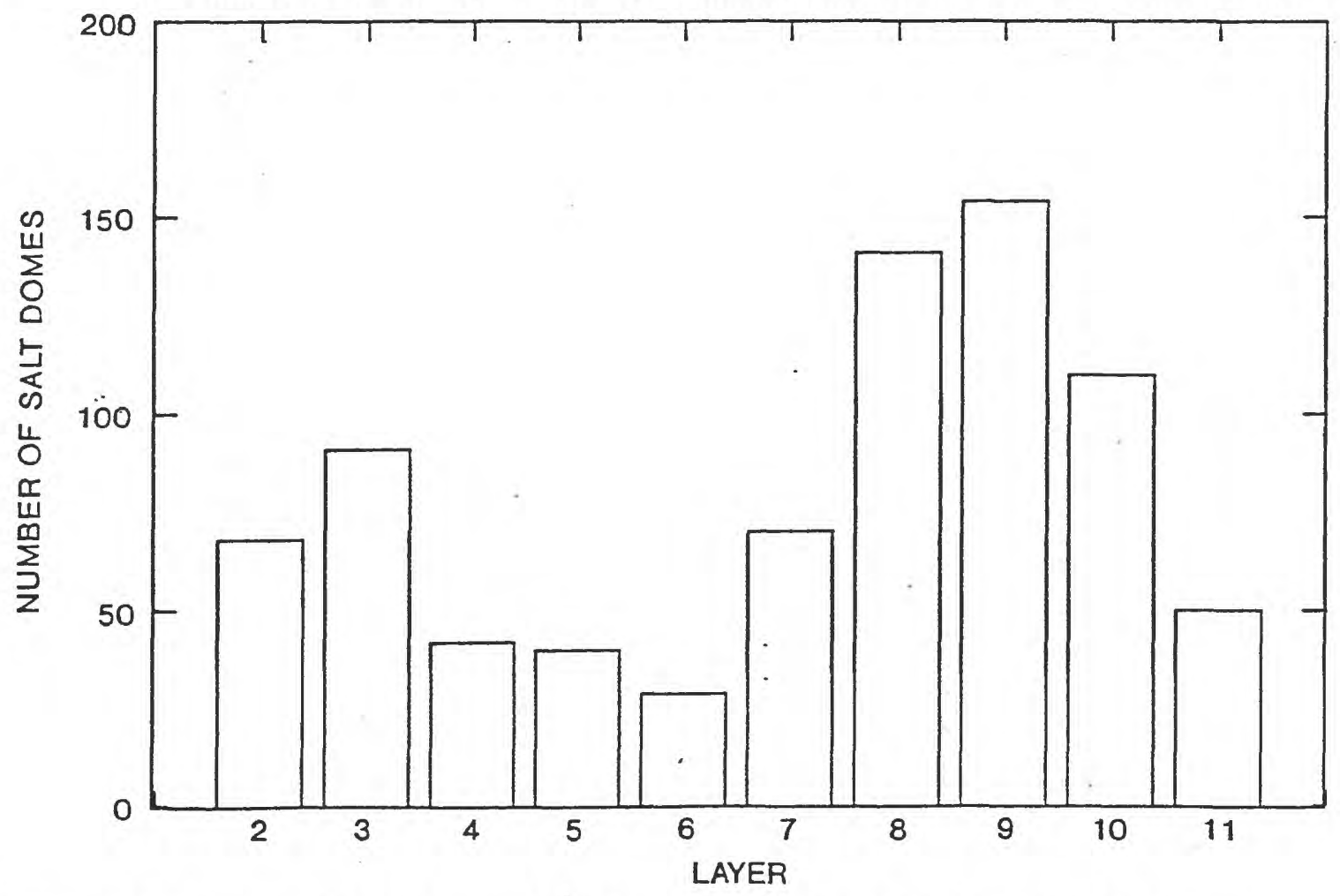

Figure 12.--Number of salt domes that penetrate the base of the indicated layer. The number of domes terminating within layers is given in table 2. 


\section{DOME NAME CODING SYSTEM}

Due to space limitations, a letter and number coding system was used to identify each salt dome on the map (plate 1). Offshore domes are symbolized by the offshore block number. Domes without published names have an identifying code printed in red on plate 1. Offshore block numbers increase toward the south within each block. Onshore domes generally are symbolized by four letters from their name. If the name is only one word then the code is the first four letters (example, Race for Raceland). If the name is more than one word then the code is the first letter of each word with the last word filling out the four characters (example, VPar for Valley Park, BdGl for Bayou des Glaizes, and WCBB for West Cote Blanche Bay). If duplicate codes occurred the code was slightly modified, usually the second letter from the first word was added (example, $\mathrm{BaHi}$ for Barbers Hill and BiHi for Big Hill). Onshore domes without published names use a similar system for county or parish names with the fourth character occupied by the sequential number (example, JDal for Jefferson Davis 1). Duplicate codes are handled in a similar fashion (example, Jff 1 for Jefferson County, Texas, and Jef 1 for Jefferson Parish, Louisiana).

\section{DATA DESCRIPTION}

Salt domes are listed alphabetically by State and then by area of salt dome occurrence in table 2 (at back of report). The distribution of salt domes among the areas is shown in figure 13. A code has been used in table 2 to show which references identified and mapped each entry as a salt dome. Specific data about each of the 624 domes was included in table 2 wherever available, including: depth to caprock and depth to salt (Anderson and others, 1973; Halbouty, 1979; Jackson and Seni, 1984; 'and Stipe, $1960,1962,1980)$. When depth discrepancies occurred between sources the shallowest depth and generally the latest source was used. Size of the domes is shown by diameter of dome top (Anderson and others, 1973; Stipe, 1960, 1962, 1980) and the volume of salt above a depth of 10,560 feet, the presumed depth of what is termed "mother salt" in Halbouty (1979, tables 8-3 through 8-8).

The volume of salt is a more accurate measurement of dome size than diameter, because diameter can vary greatly with depth. Mature, piercement salt structures may contain most of their salt at shallow depths with the cross sectional area of the dome decreasing with depth. Less mature salt structures are found at greater depths and usually have a mounded shape so that their cross sectional area increases with depth. A depth of 10,000 feet represents the delineation between intermediate and deep salt structures in the classification of Halbouty (1979), but in Jackson and Seni (1984) 10,000 feet seems to be the cutoff between salt diapirs (piercement structures) and salt pillows (less mature, nonpiercement structures).

The land-surface or sea-bottom altitudes in table 2 are approximations. Landsurface altitudes at salt domes were estimated by interpolation from a uniform grid of altitudes spaced at 5-mile intervals. Onshore, each altitude in the grid was the average of about 90 points uniformly spaced at intervals of 30 seconds of latitude and longitude. The data set and the method used is described more fully by Williams and Williamson (1989, p. 335-336). The original data was recorded in meters, so the resolution is at least 3 feet. That is why land-surface altitude at so many salt domes near the coastline is shown as 3 feet. The grid values of sea-bottom altitude were estimated by computer contouring about 100 data points at oil wells. 


\section{SUMMARY}

Information on 624 salt domes in the Gulf of Mexico Coastal Plain of the southcentral United States and the adjacent Continental Shelf was compiled from eight published sources, 1973-84. The salt domes included are both those confirmed by drilling and those interpreted from seismic surveys. The information tabulated includes a map code; salt-dome name; location by State, area of salt-dome occurrence, county (or parish), latitude and longitude; aquifer, permeable zone, or confining unit in which the salt dome terminates; land-surface or sea-bottom altitude at the location of the salt dome; depth to the top of salt and caprock; diameter and volume of the salt dome; and the published reference from which the data were obtained.

The depth to top of salt is unknown for about 44 percent of the salt domes. Most of the domes for which the depth to salt is unknown are located in the offshore part of the Gulf Coast salt basin, predominantly offshore Louisiana. Only 12 percent of the domes are known to terminate below the gulf coast aquifer systems. The remaining 44 percent penetrate the gulf coast aquifer systems.

Salt-dome locations and outlines are shown on a map at a scale of $1: 1,500,000$. The locations of salt domes that penetrate each of 10 aquifers of the gulf coast aquifer systems are shown on smaller scale maps. 


\section{REFERENCES CITED}

Anderson, R.E., Eargle, D.H., and Davis, B.O., 1973, Geologic and hydrologic summary of salt domes in Gulf Coast region of Texas, Louisiana, Mississippi, and Alabama: U.S. Geological Survey Open-File Report 4339-2, 294 p.

Grubb, H.F., 1984, Planning report for the Gulf Coast Regional Aquifer-System Analysis in the Gulf of Mexico Coastal Plain, United States: U.S. Geological Survey WaterResources Investigations Report 84-4219, $30 \mathrm{p}$.

----1987, Overview of the Gulf Coast Regional Aquifer-System Analysis, South-Central United States, in Vecchioli, John, and Johnson, A.I., eds., Regional aquifer systems of the United States, aquifers of the Atlantic and Gulf Coastal Plain, American Water Resources Association Monograph no. 9, p. 108-118.

Halbouty, M.T., 1979, Salt domes, Gulf Region: United States and Mexico (2nd ed.): Houston, London, Paris, and Tokyo, Gulf Publishing Company, 561 p.

Hosman, R.L., and Weiss, J.S., 1988, Geohydrologic units of the Mississippi embayment and Texas coastal uplands aquifer systems, south-central United States: U.S. Geological Survey Open-File Report 88-316, 21 p.

Jackson, M.P.A., and Seni, S.J., 1984, Atlas of salt domes in east Texas: University of Texas, Bureau of Economic Geology Report of Investigations no. 140, 102 p.

Louisiana Geological Survey, compiler, 1981a, Offshore Louisiana oil and gas map prepared for Department of Natural Resources, scale 1:380,160, 1 sheet.

$1981 \mathrm{~b}$, Oil and gas map of Louisiana prepared for Department of Natural Resources, scale $1: 380,160,1$ sheet.

Martin, R.G., 1980, Distribution of salt structures in the Gulf of Mexico: Map and descriptive text: U.S. Geological Survey Miscellaneous Field Studies Map 1213, scale $1: 2,500,000,2$ sheets, 8 p.

New Orleans and Lafayette Geological Societies, 1973, Louisiana oil and gas fields, $123 \mathrm{p}$.

Stipe, J.C., ed., 1960, Salt domes of south Louisiana, v. 1: New Orleans Geological Society, $145 \mathrm{p}$.

----1962, Salt domes of south Louisiana, v. 2: New Orleans Geological Society, 107 p.

-.--1980, Salt domes of south Louisiana, v. 3: New Orleans Geological Society, 142 p.

U.S. Department of the Interior, 1983, Geologic and geomorphic features: Minerals Management Service, Gulf of Mexico OCS Regional Office, map, Visual No. 2, scale $1: 1,200,000$, and Visual No. 5, scale 1:800,000, 2 sheets.

Weiss, J.S., and Williamson, A.K., 1985, Subdivisions of thick sedimentary units into layers for simulation of ground-water flow: Ground Water, v. 23, no. 6, p. 767-774.

Weiss, J.S., 1990, Geohydrologic units of the coastal lowlands aquifer system, southcentral United States: U.S. Geological Survey Open-File Report 90-173, 30 p.

Williams, T.A., and Williamson, A.K., 1989, Estimating water-table altitudes for regional ground-water flow modeling, U.S. Gulf Coast: Ground Water, v. 27, no. 3, p. $333-340$.

Williamson, A.K., Grubb, H.F., and Weiss, J.S., 1990, Ground-water flow in the gulf coast aquifer systems, south-central United States--A preliminary analysis: U.S. Geological Survey Water-Resources Investigations Report 89-4071, 124 p. 
T A B L 2

22 
ปี

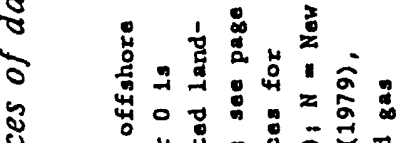

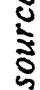

ป

हี

8

於

ป

ำ

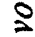

ปี

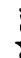

.

\%

ปัँ

ह

ธี

$\overline{5}$

s

$\frac{2}{8}$

ปั

:

ปั

है

帘

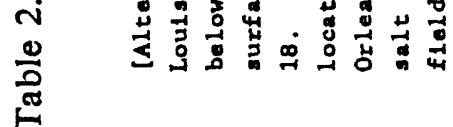

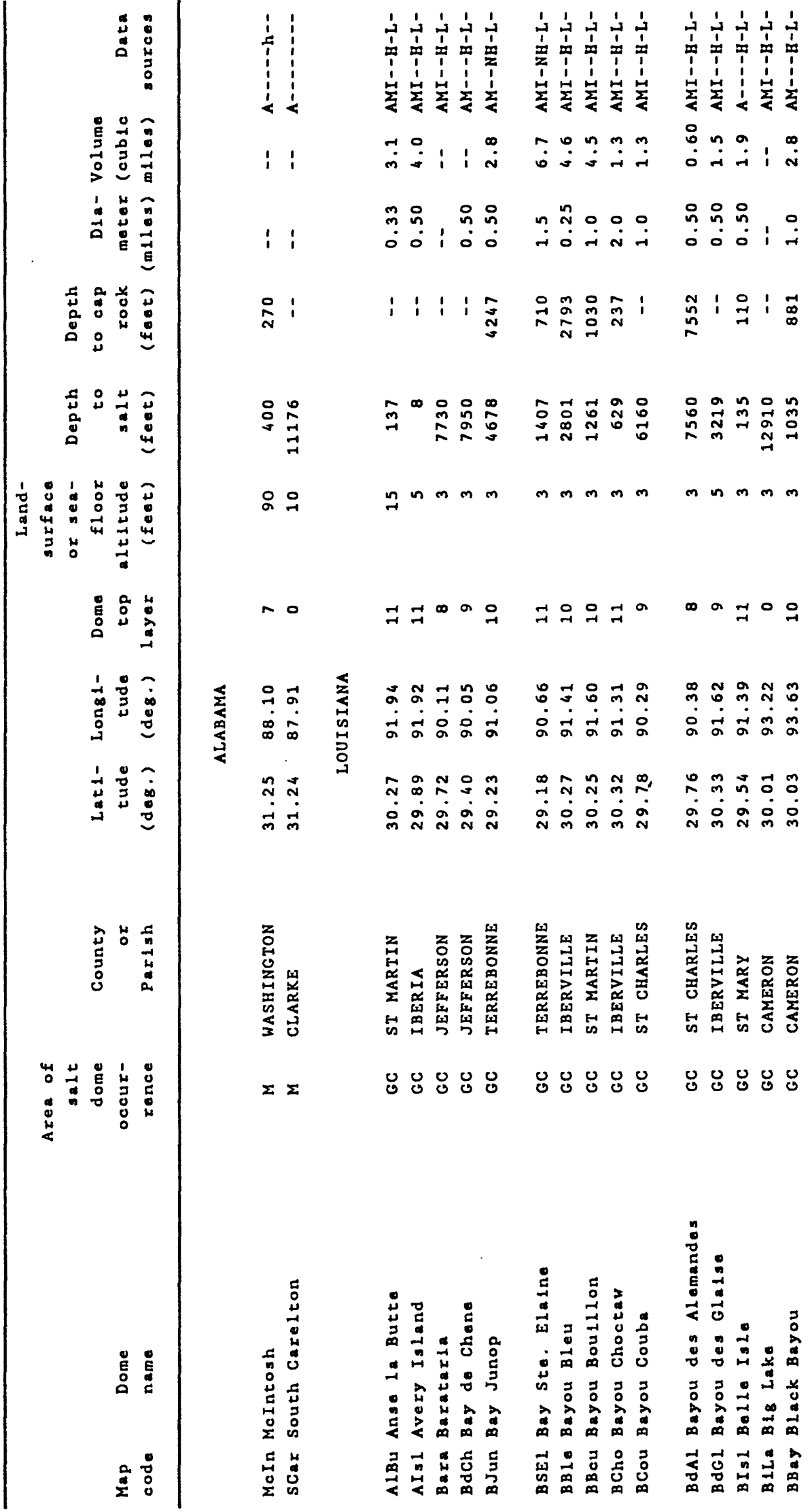




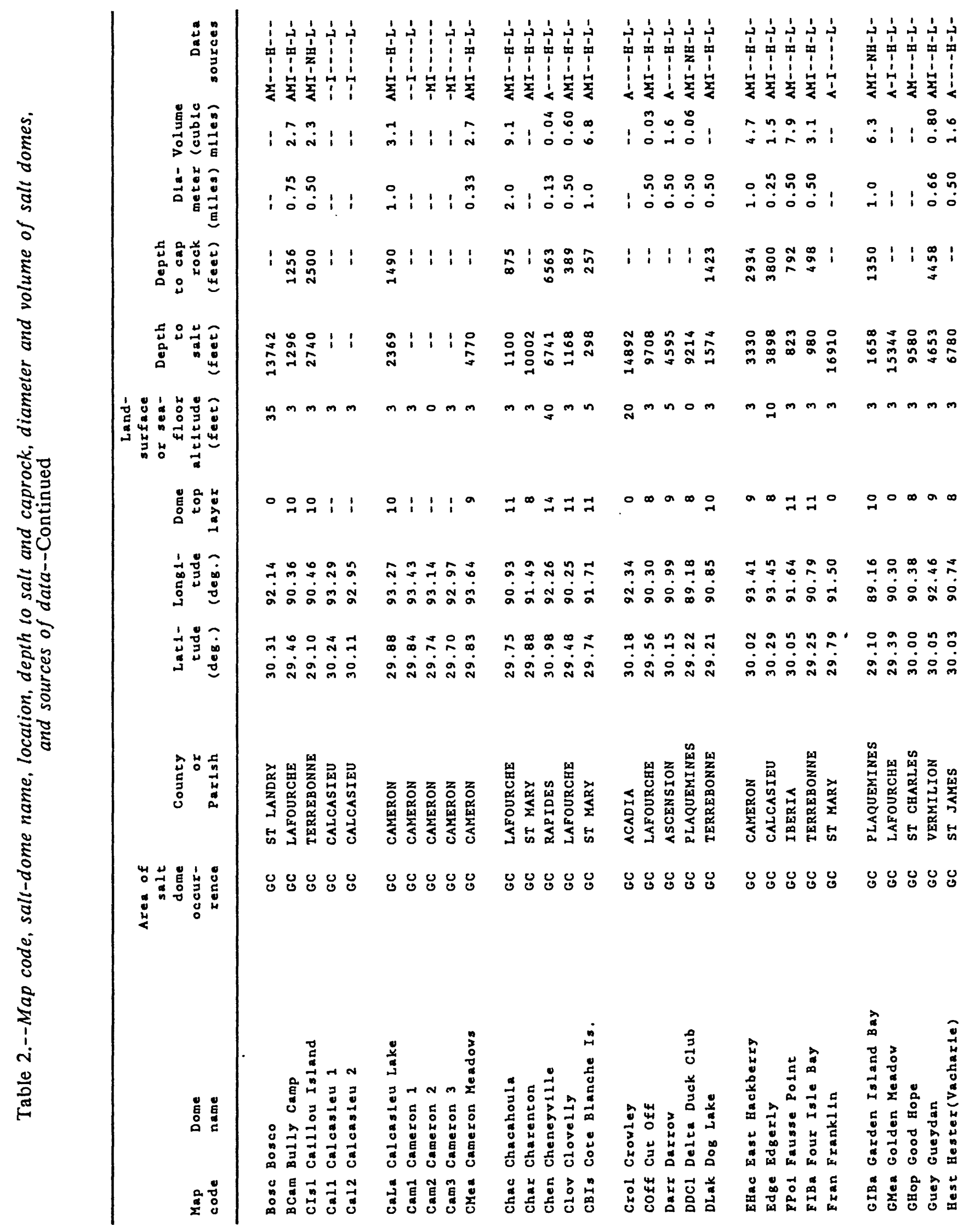




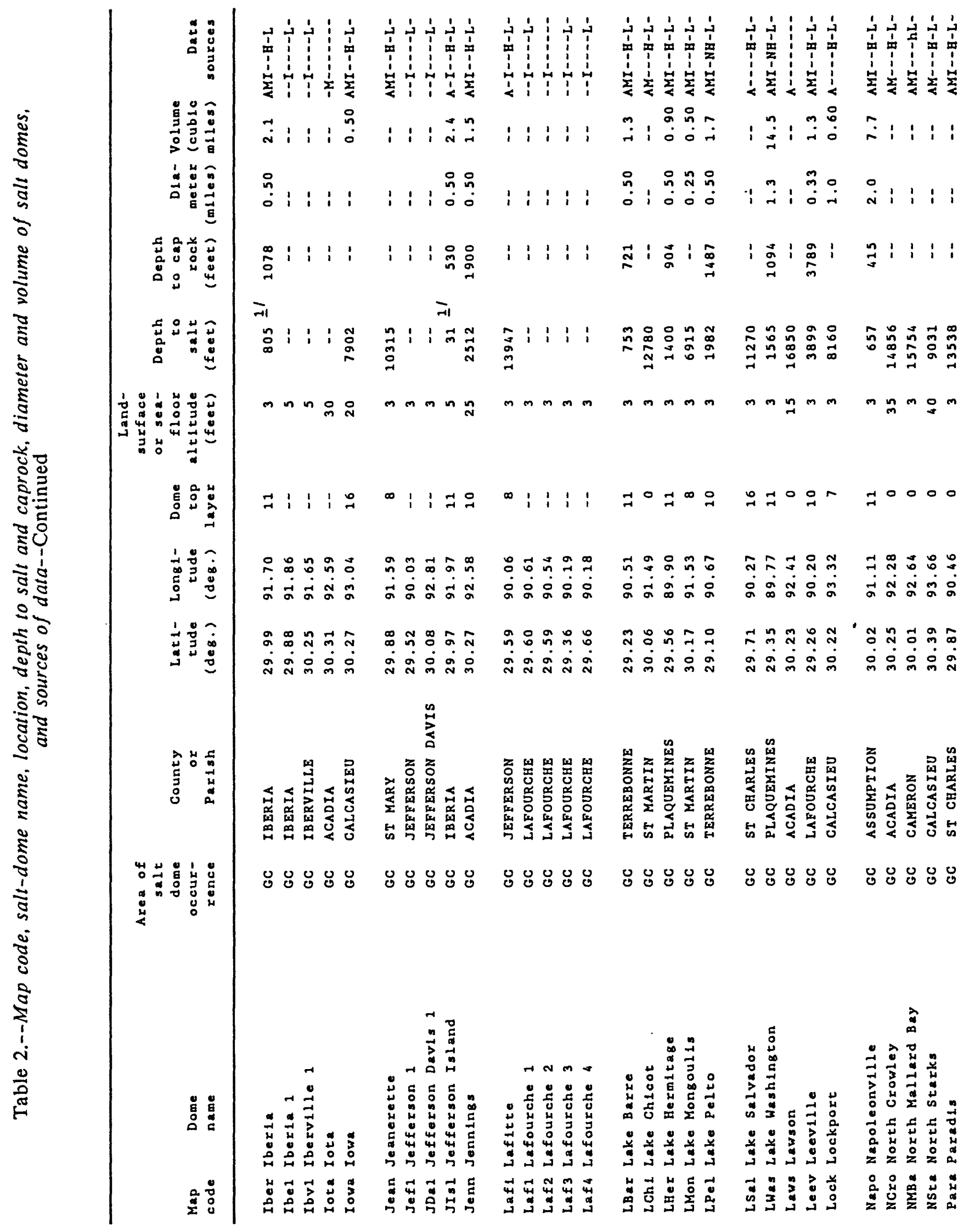




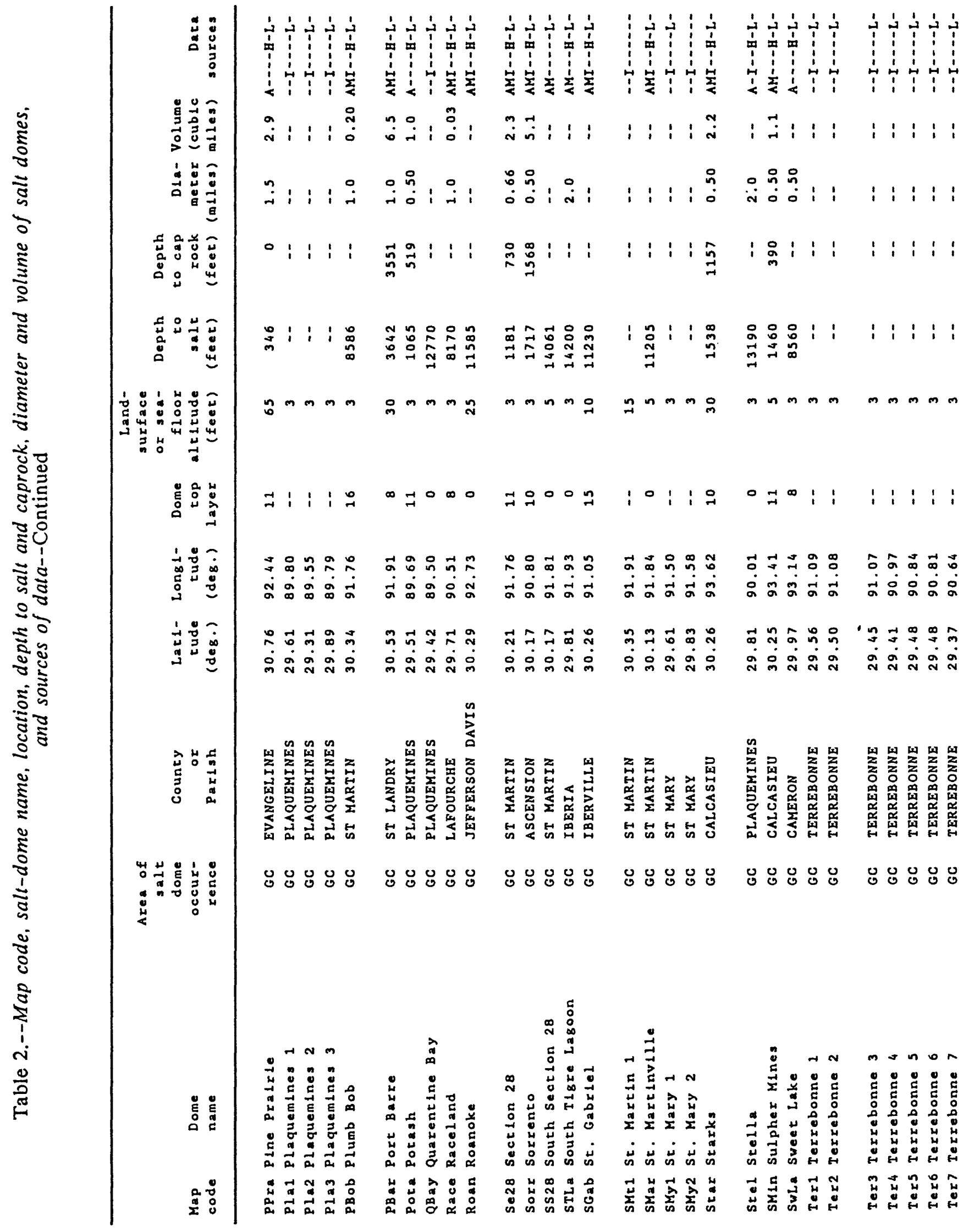




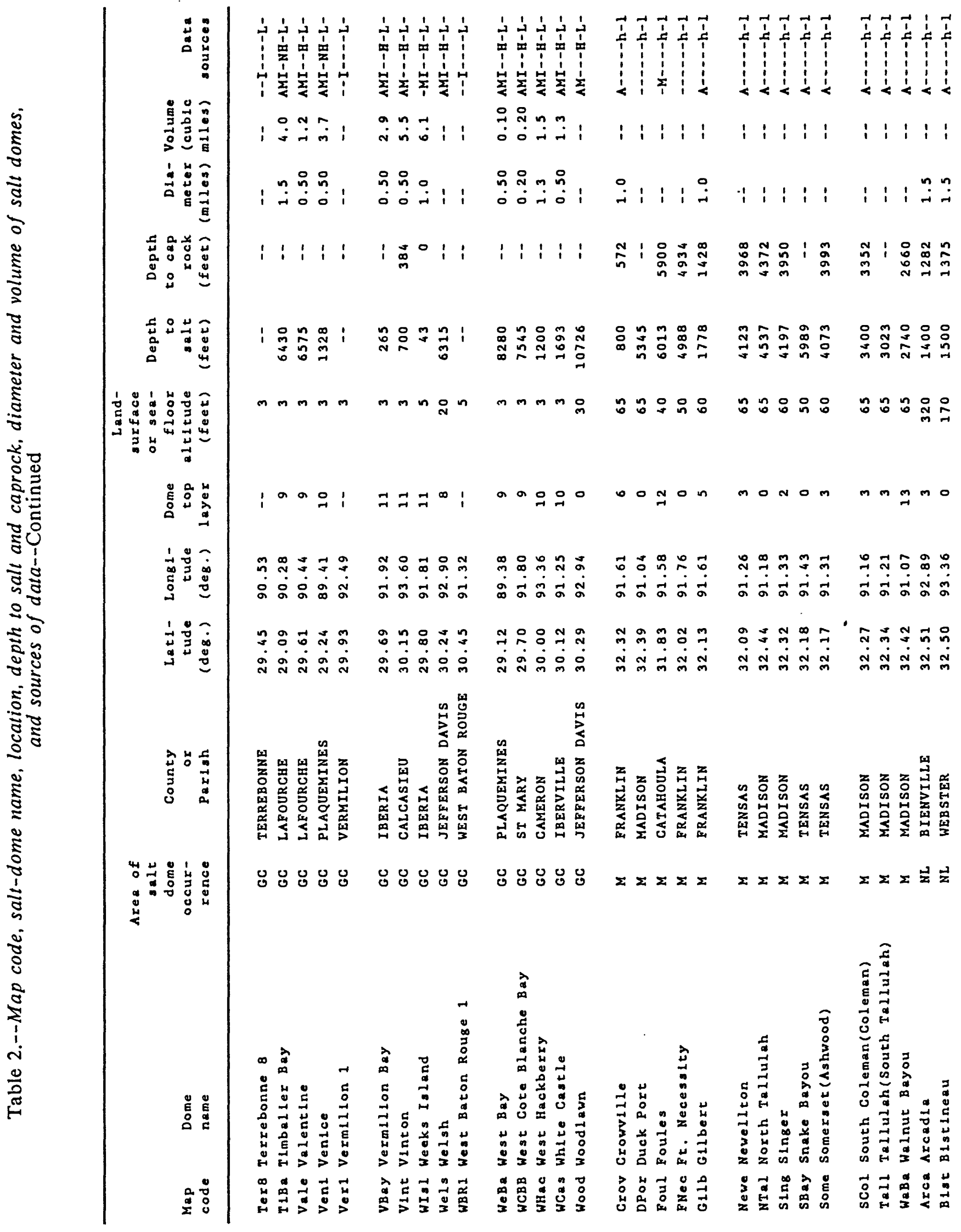




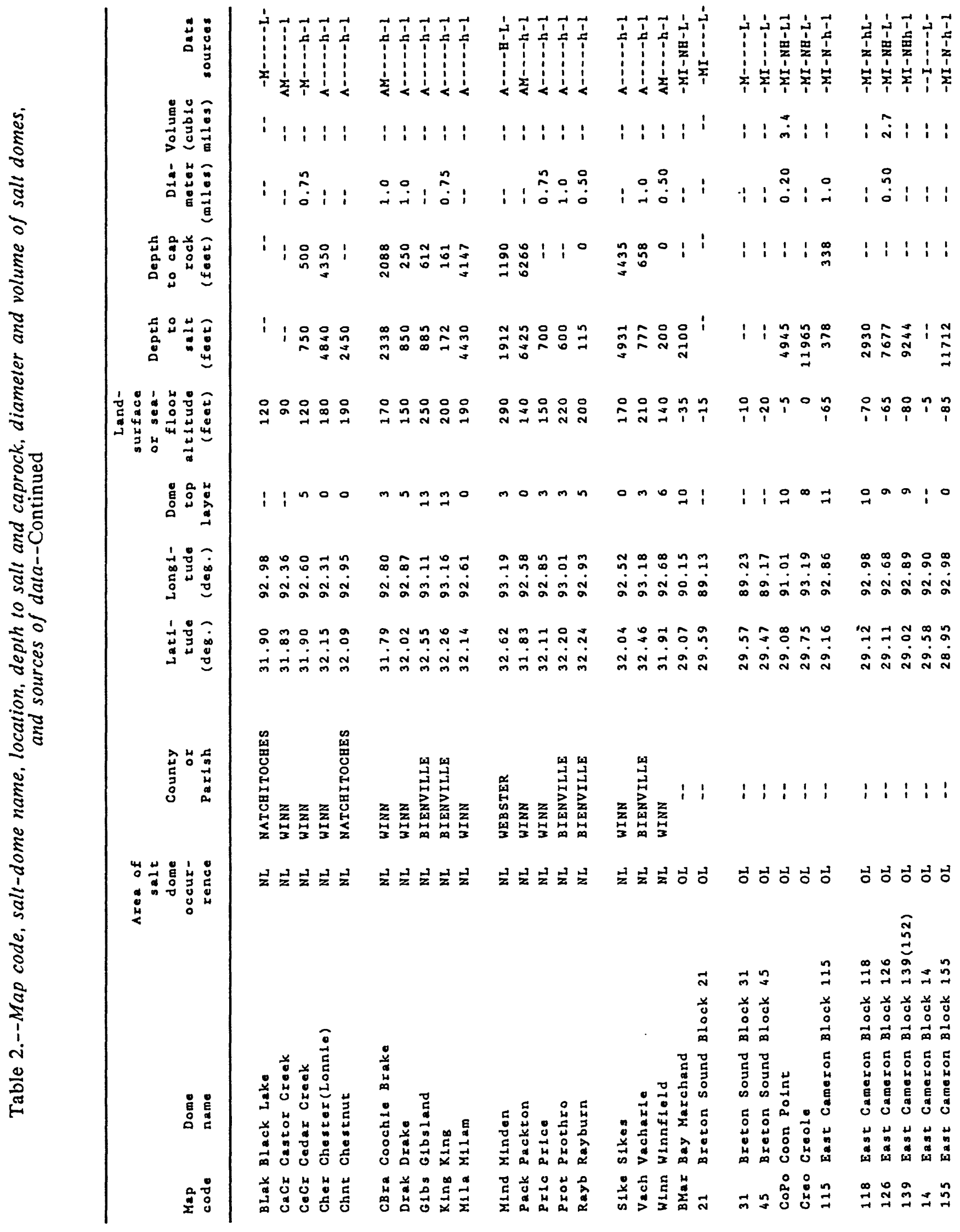




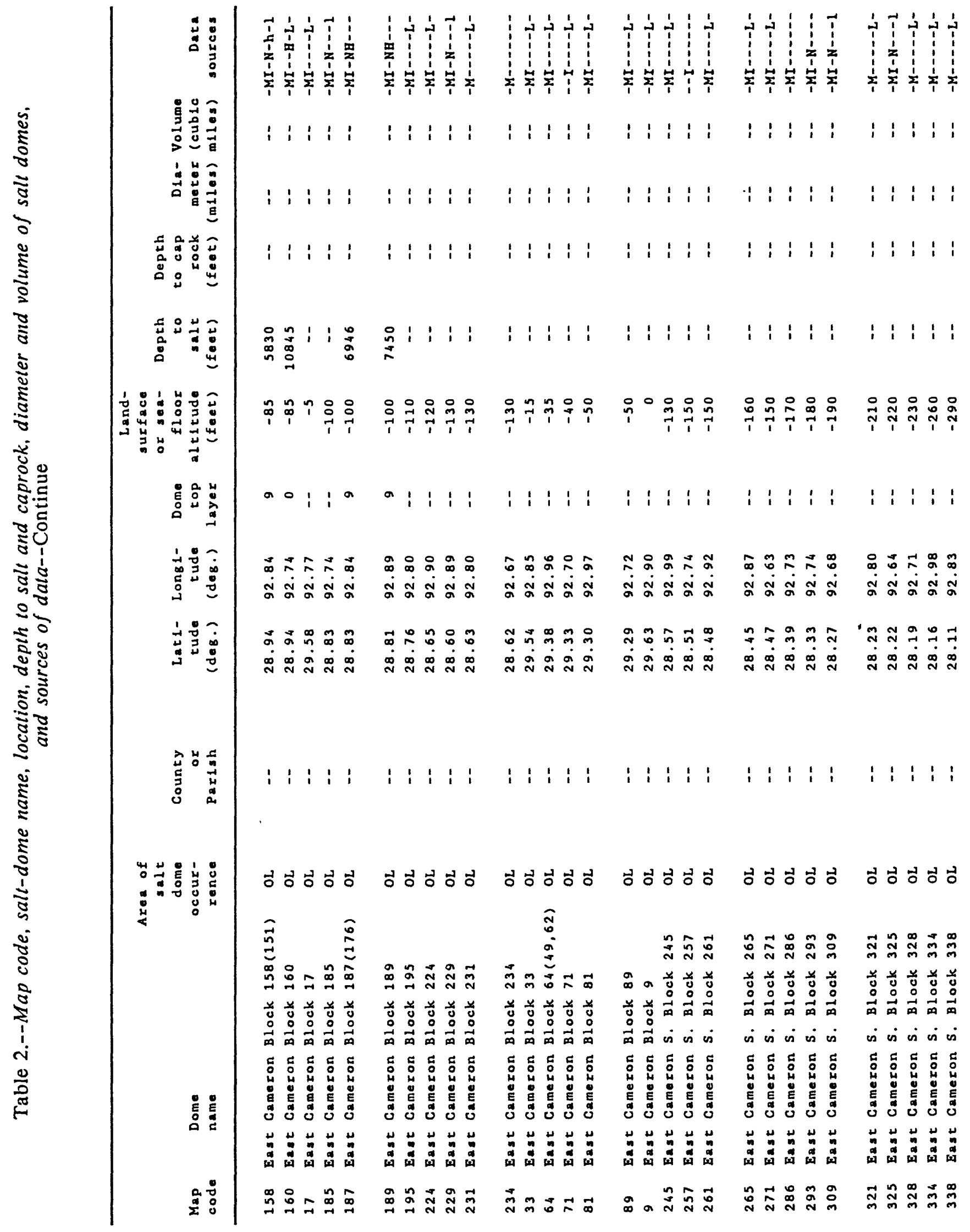




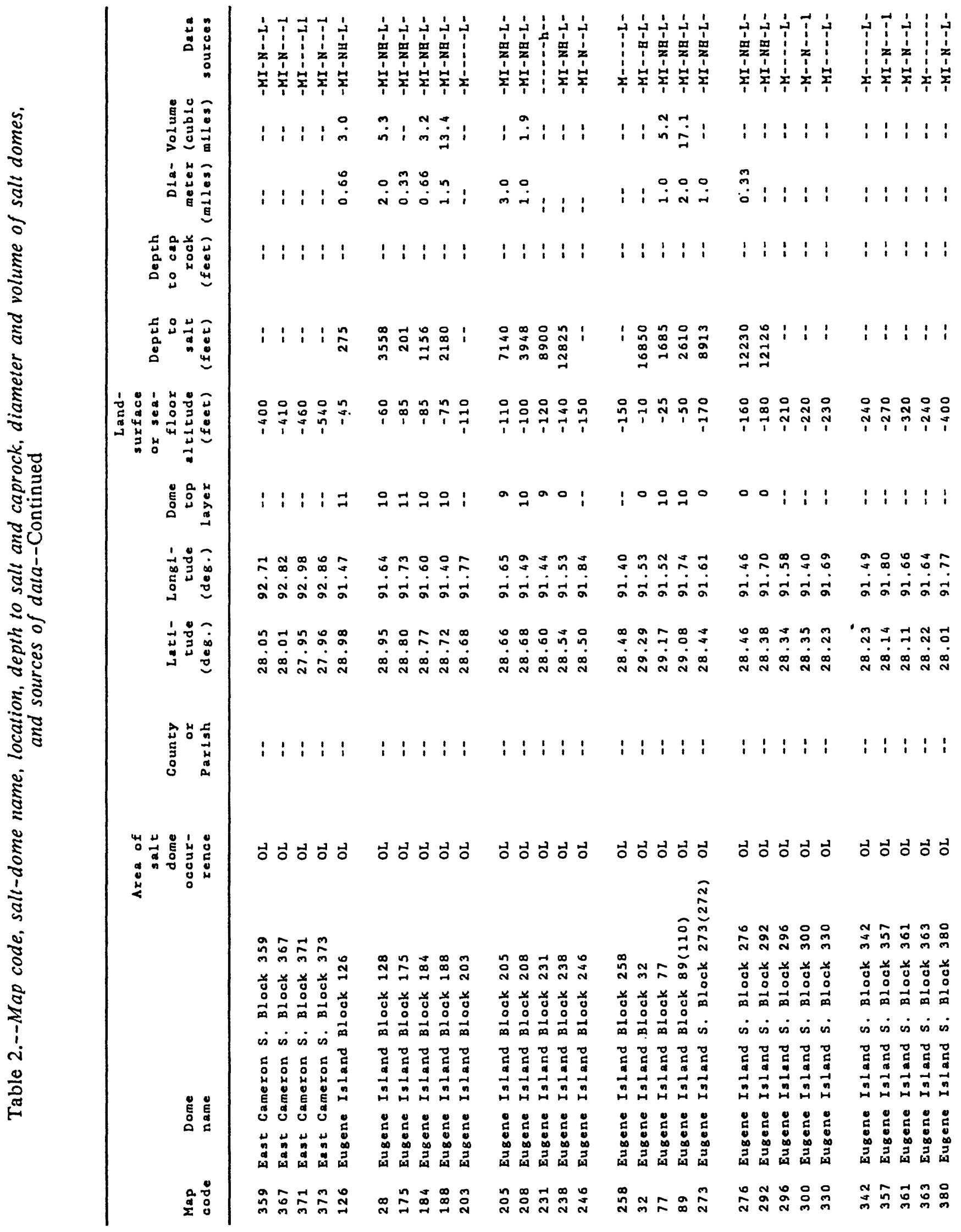




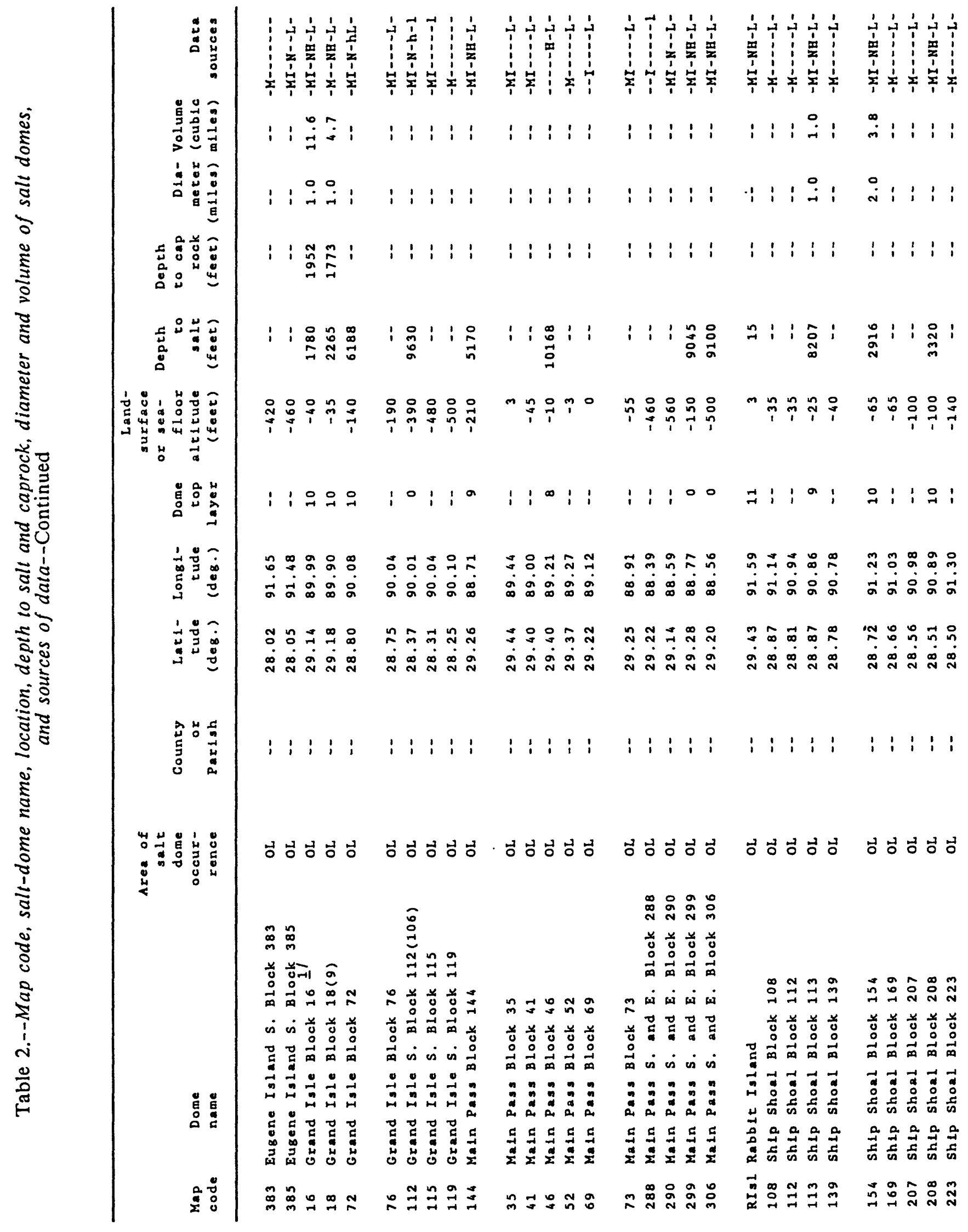




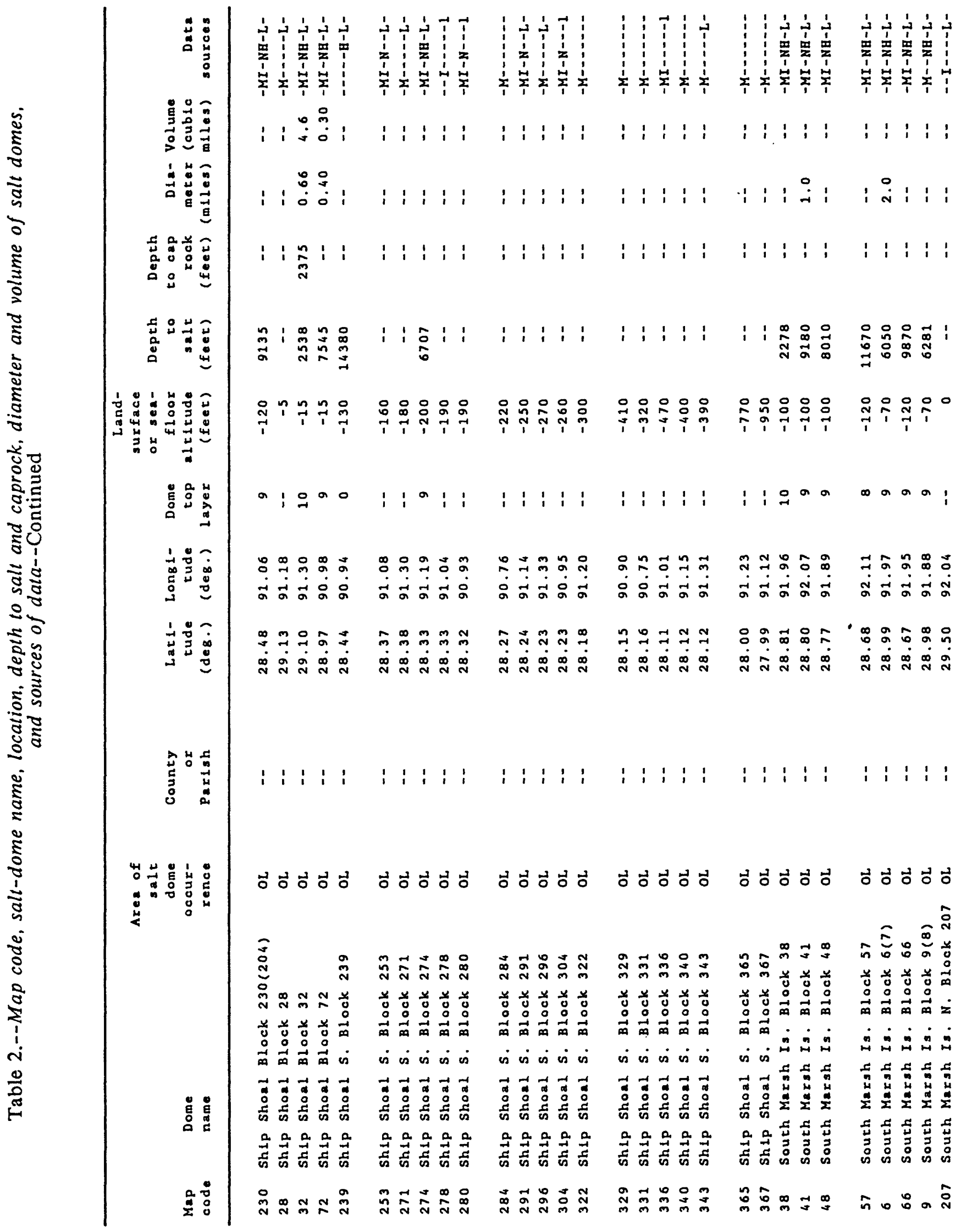




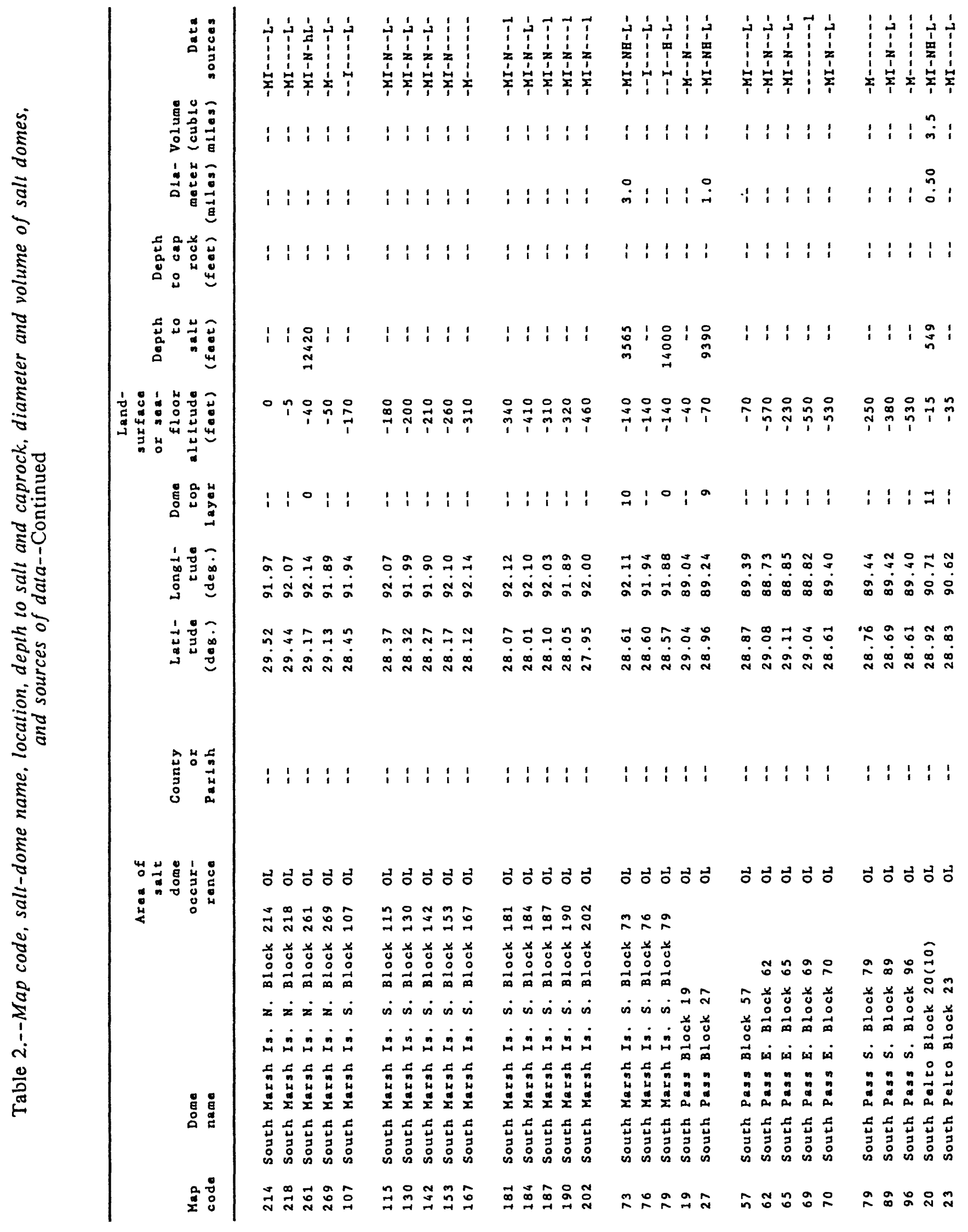




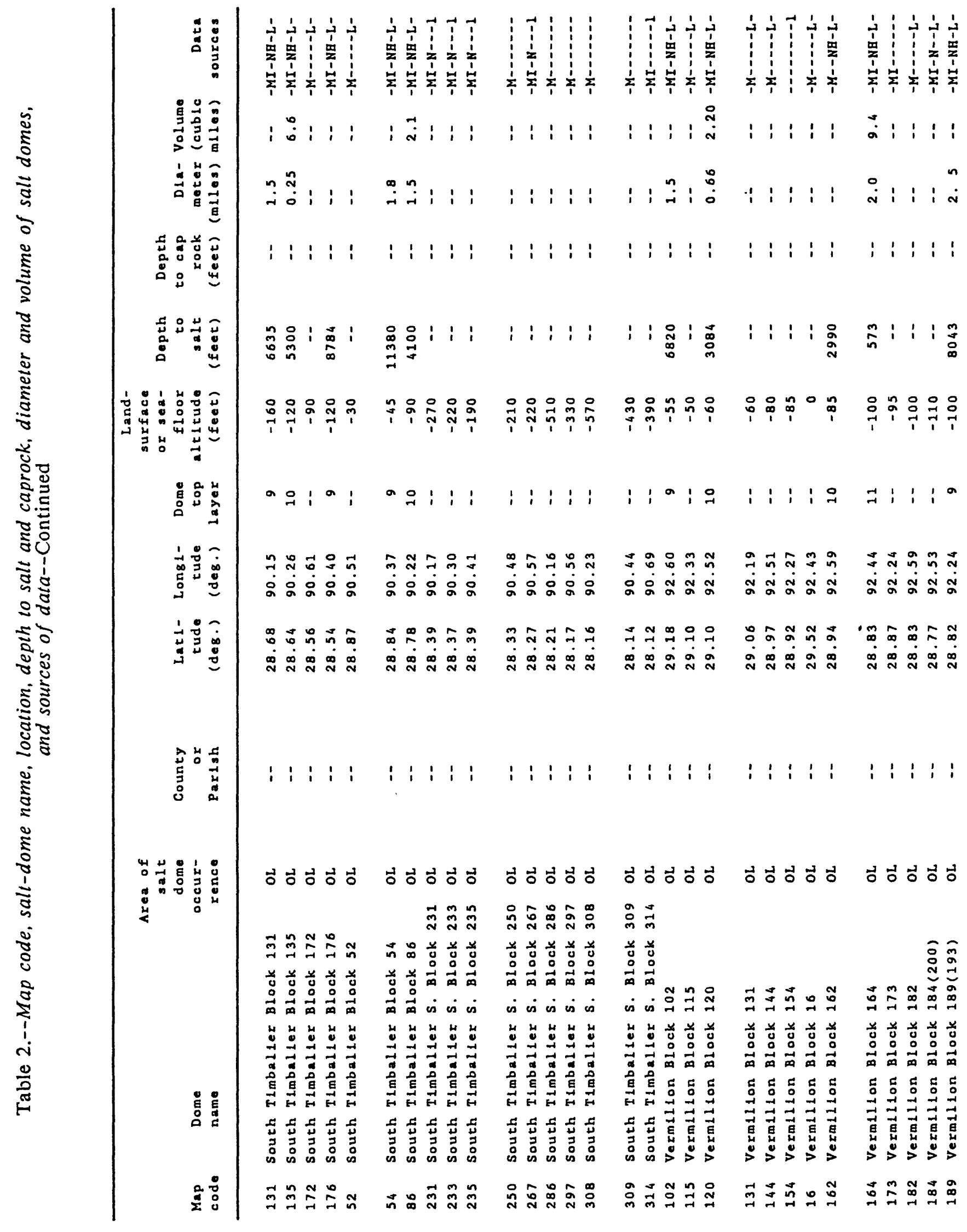




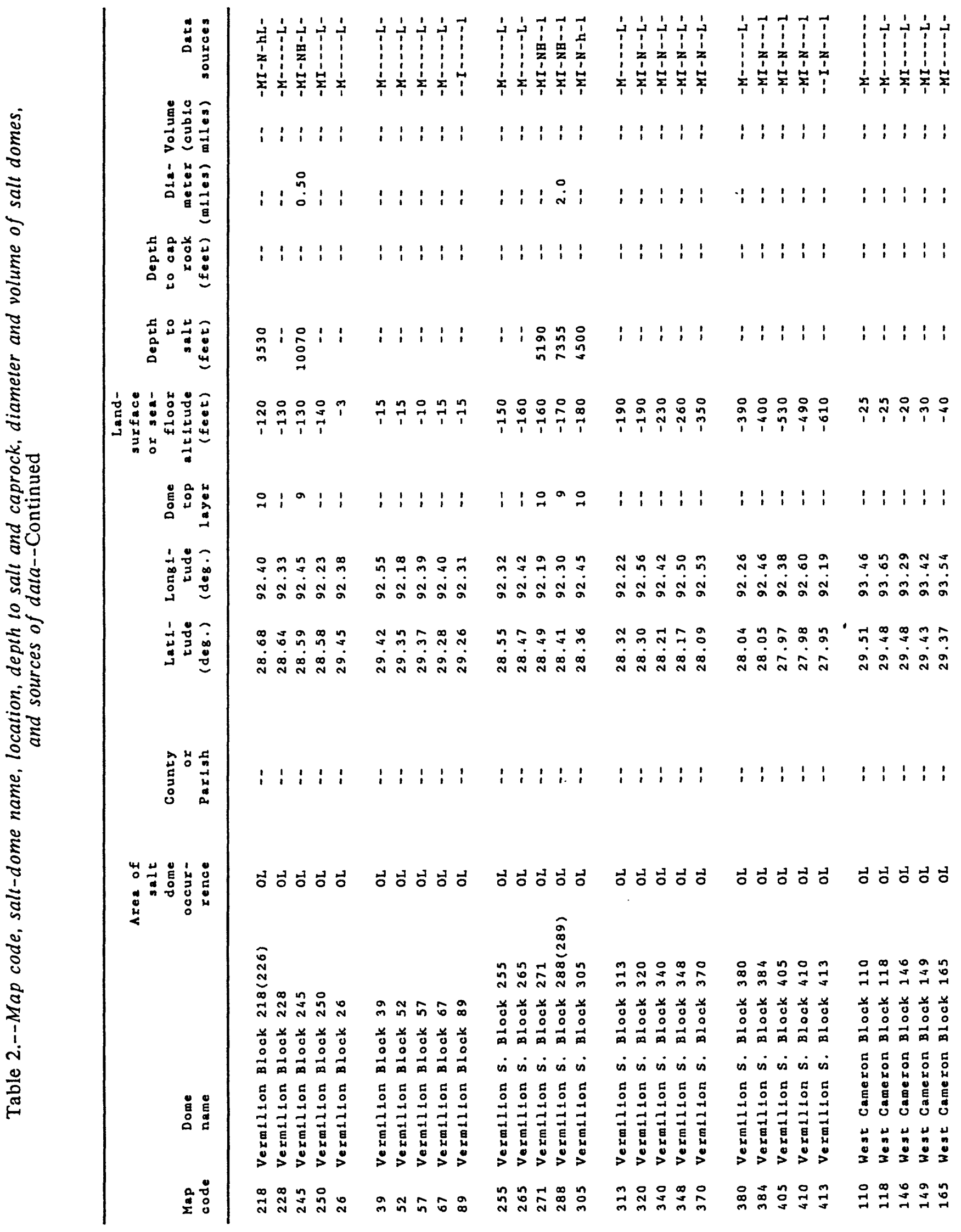




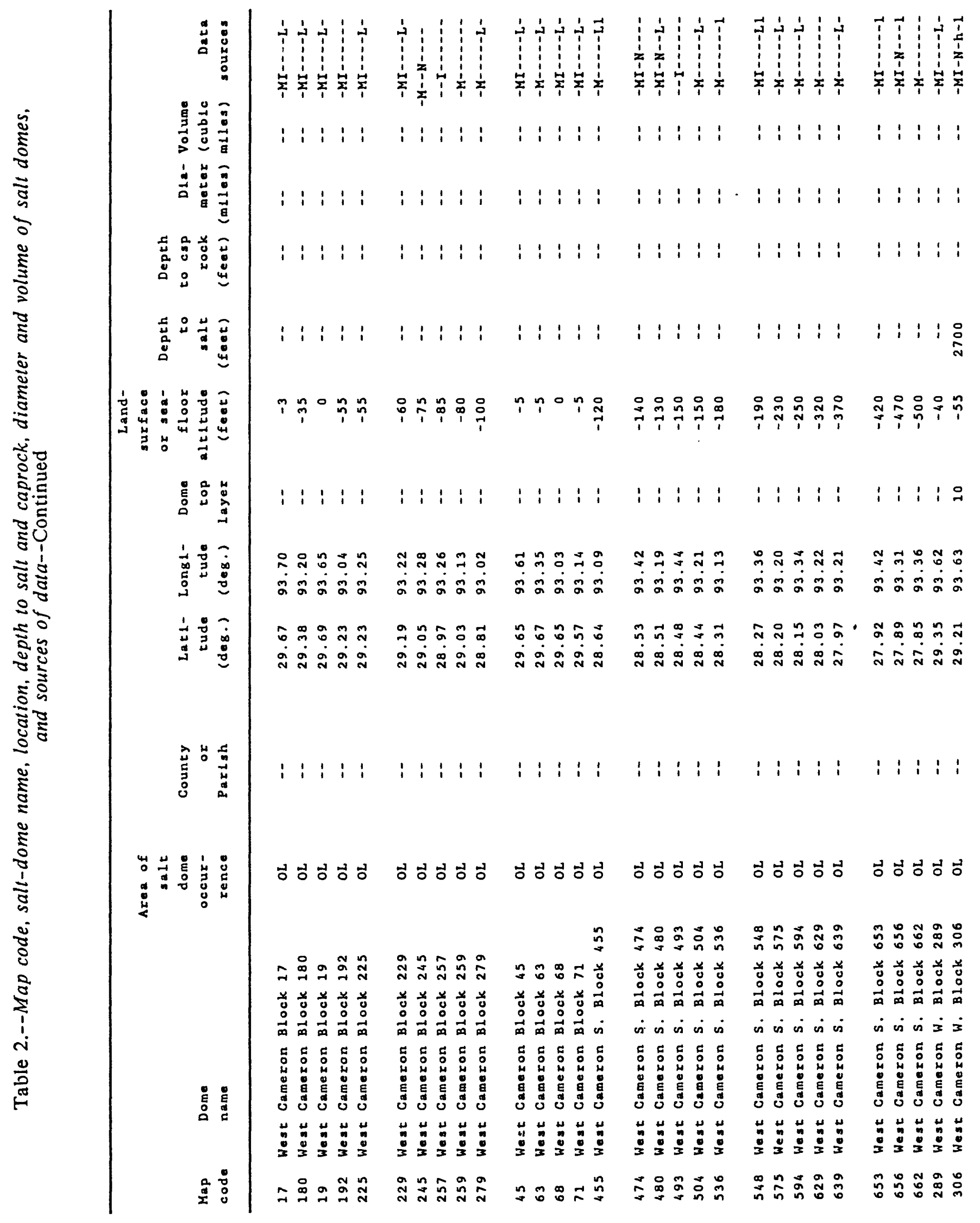




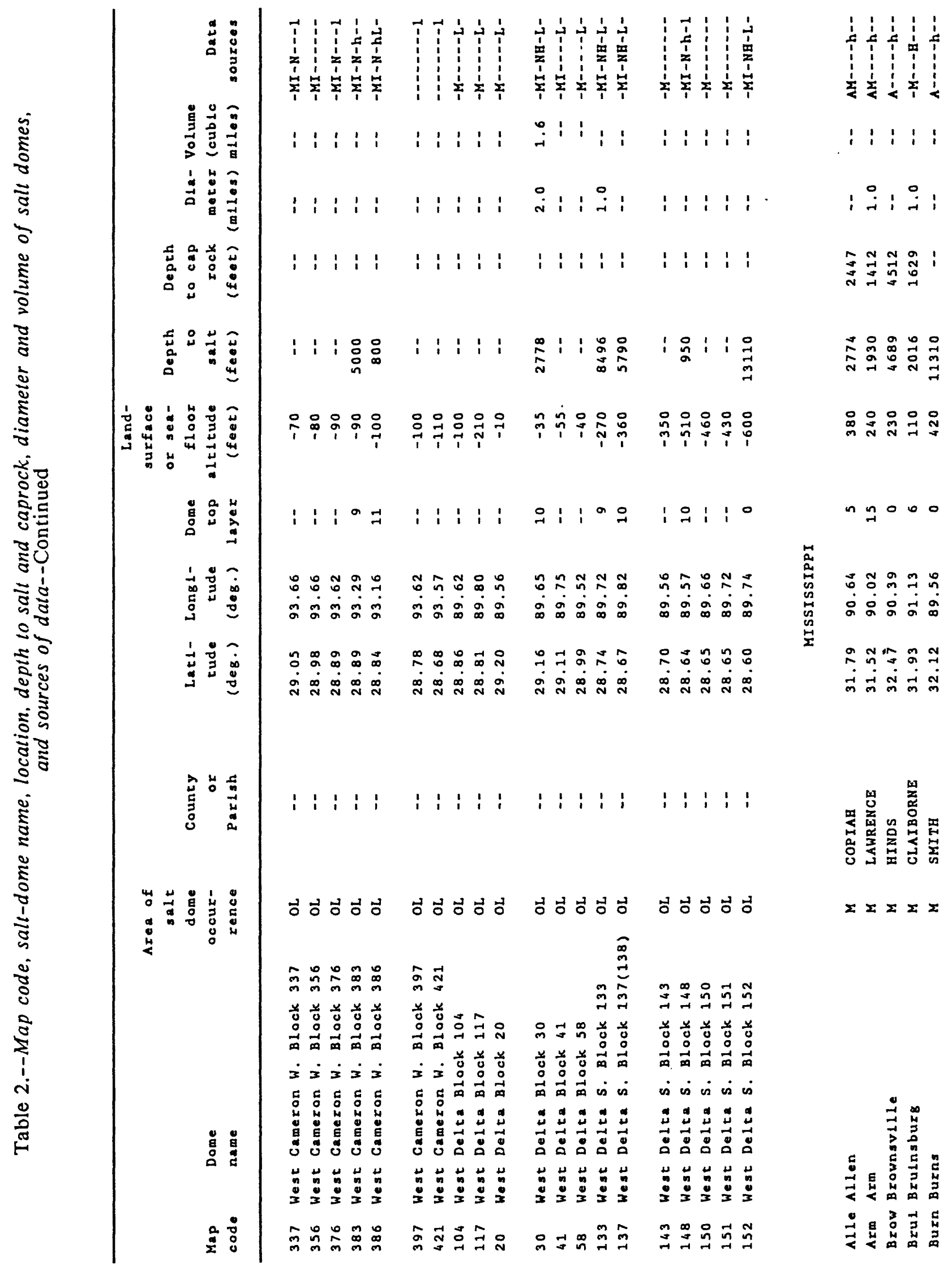




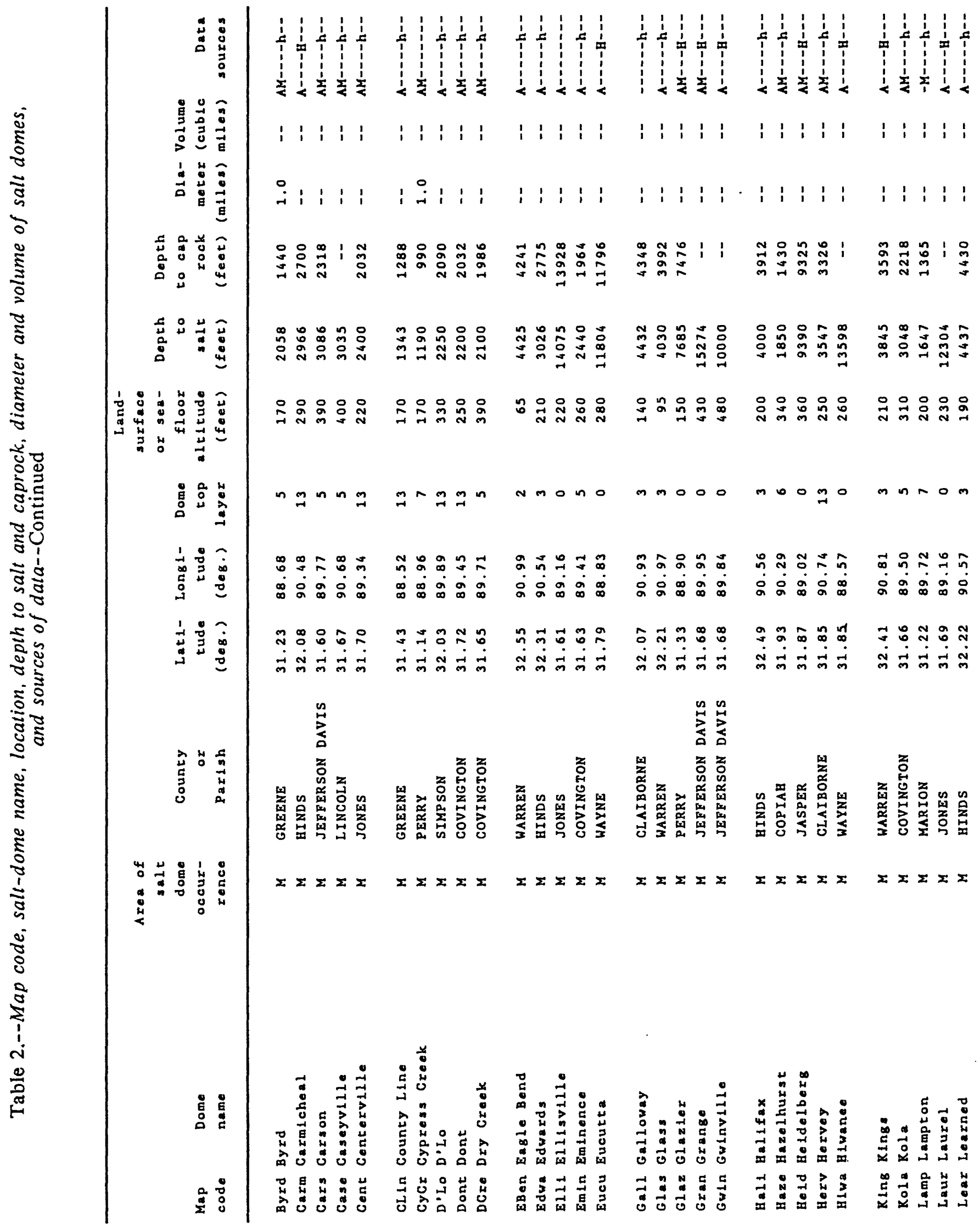




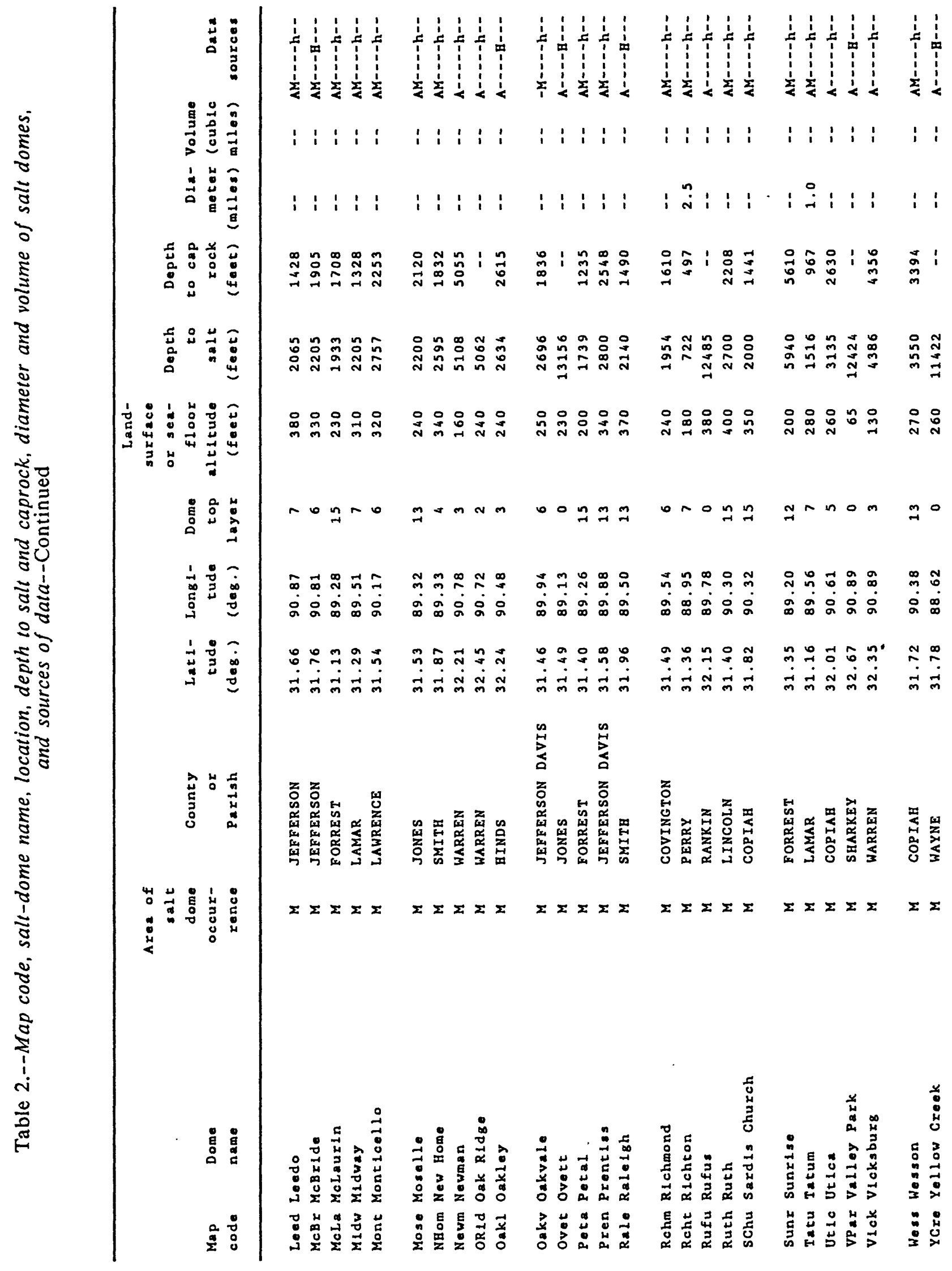




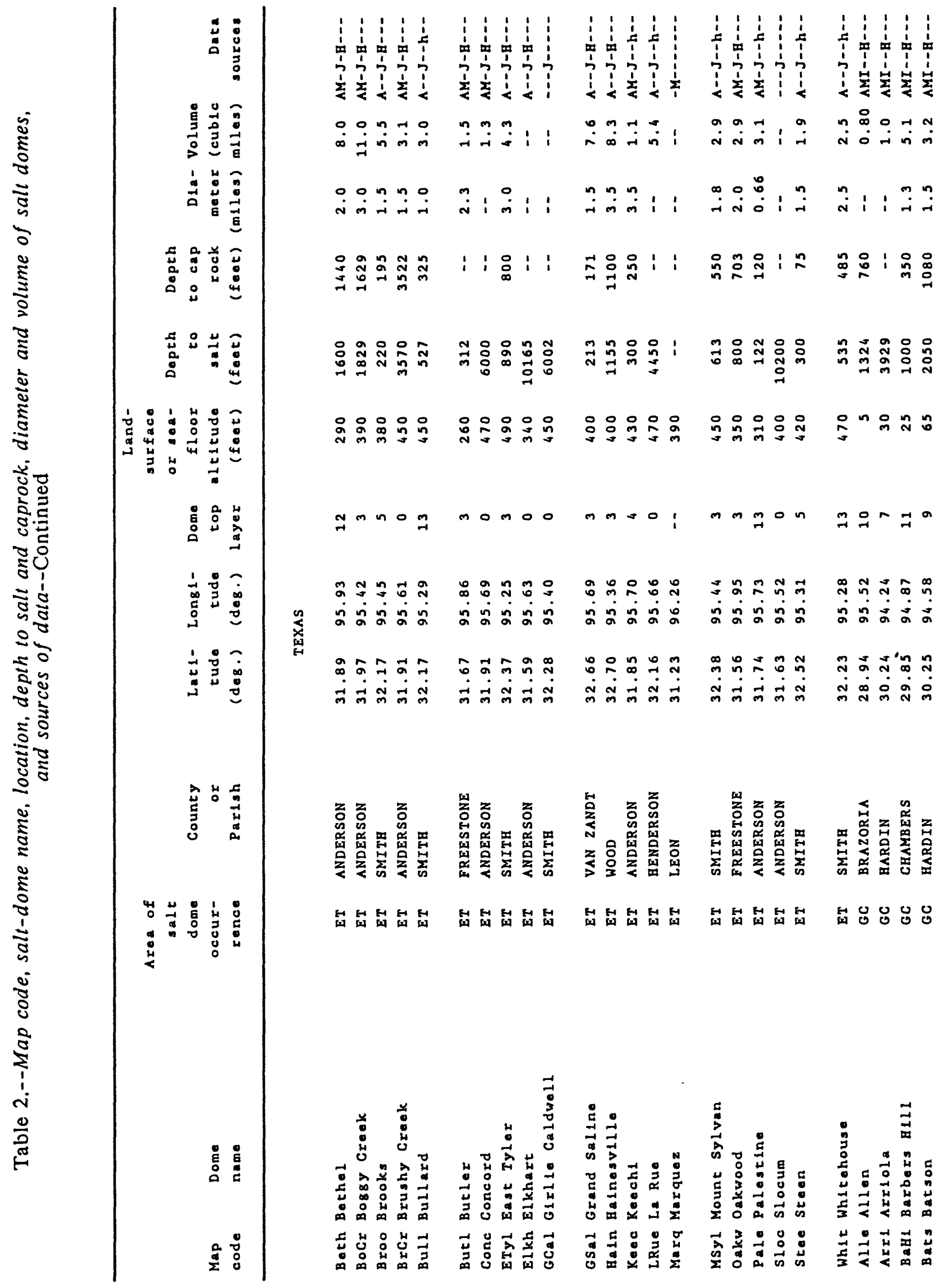




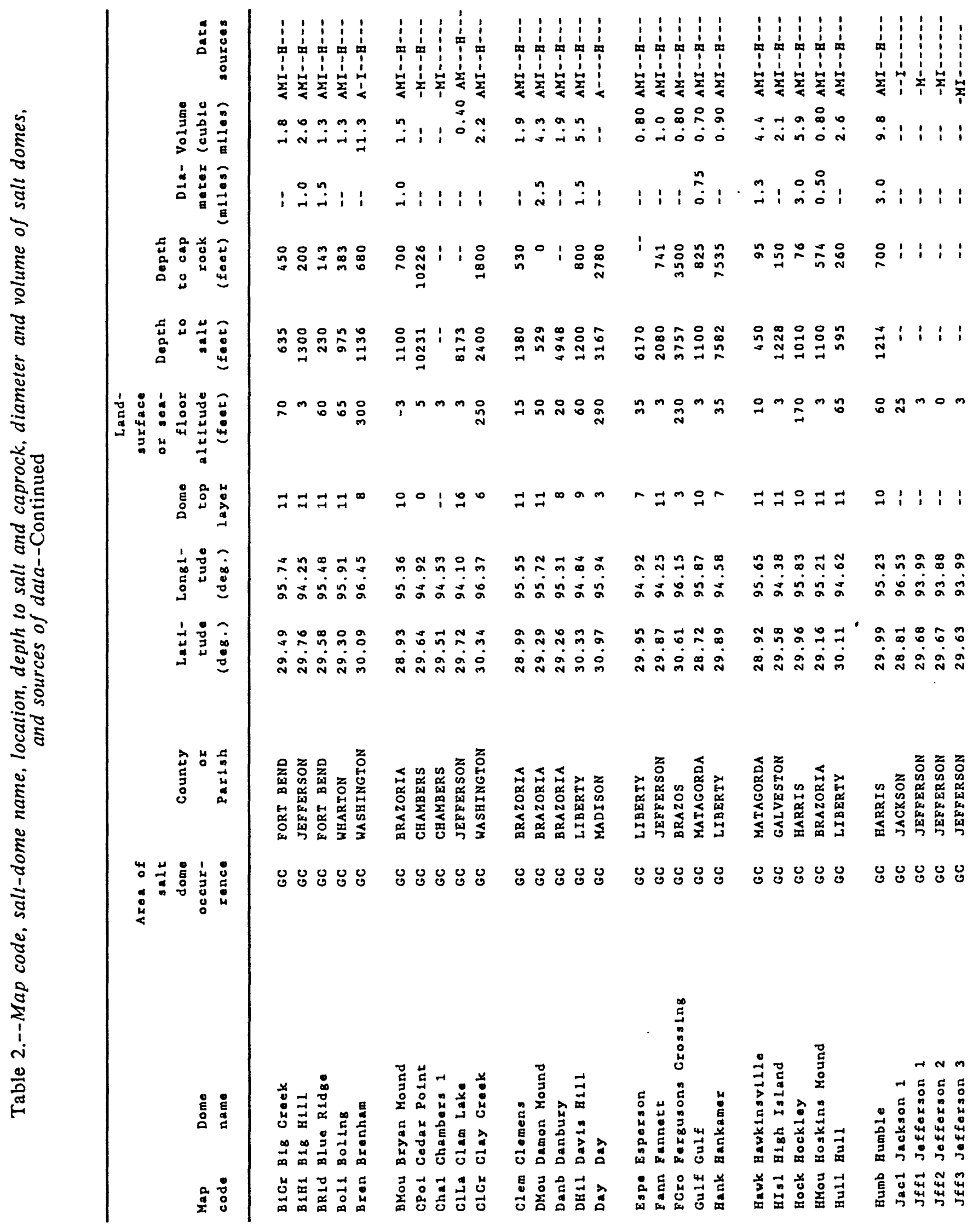




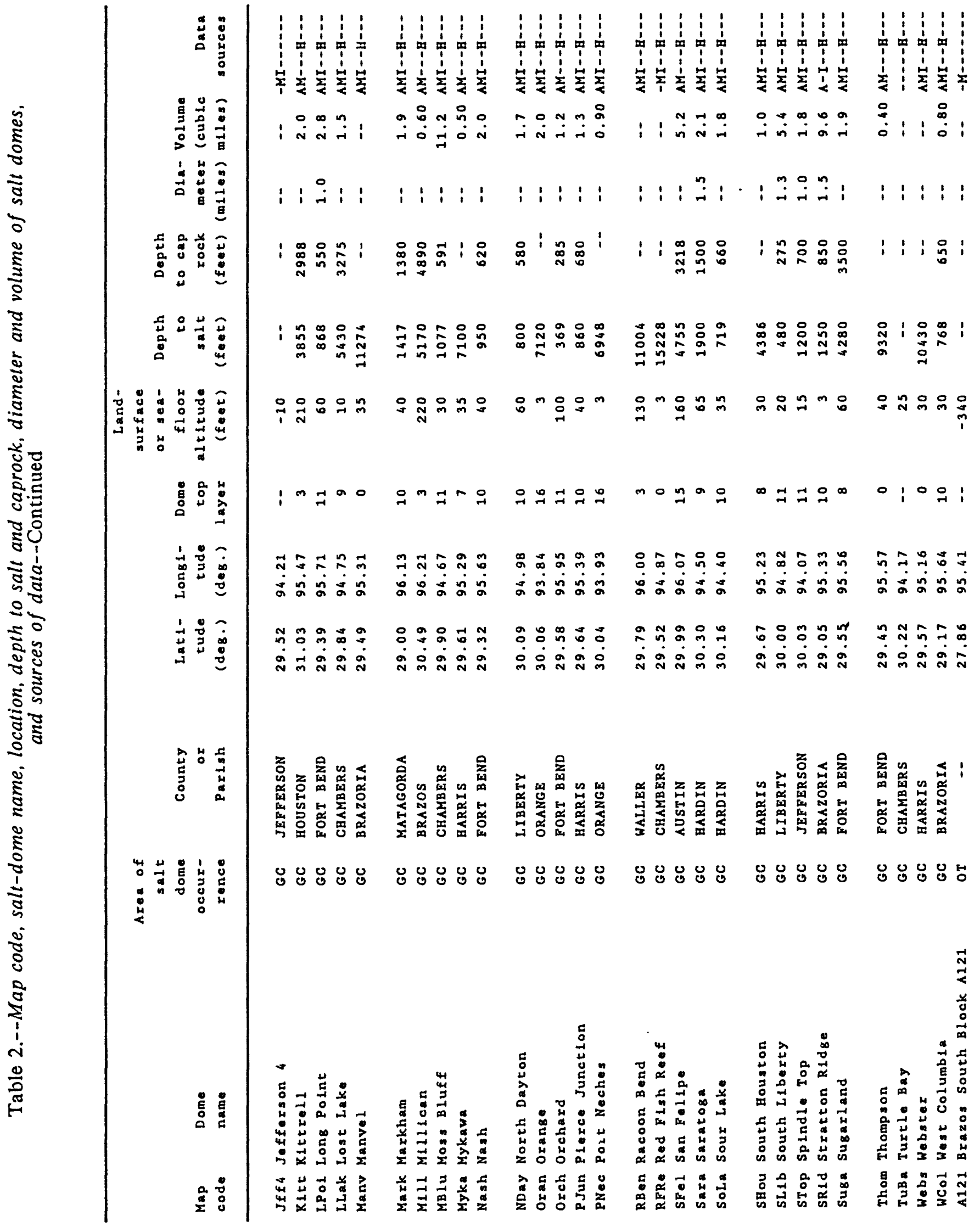




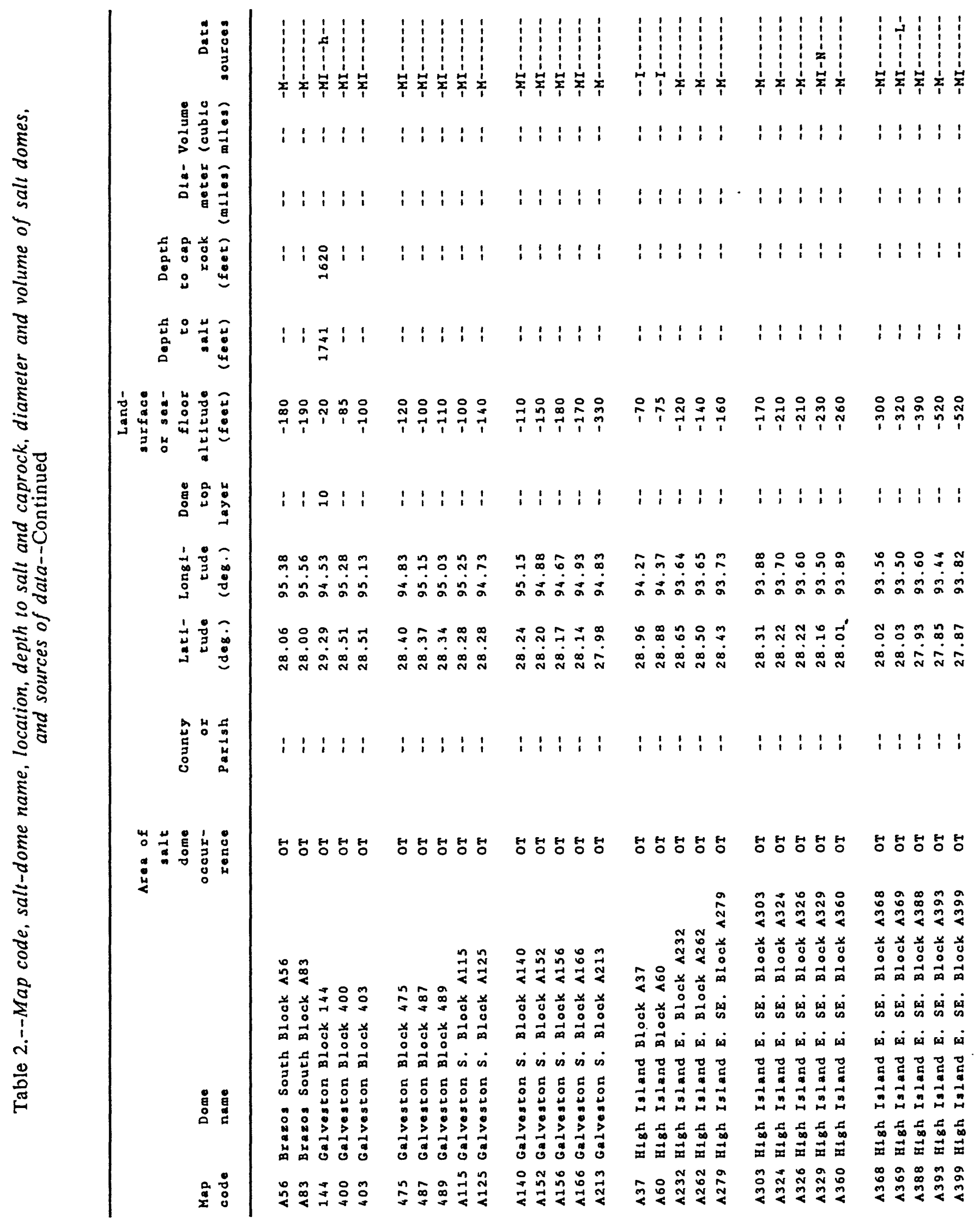




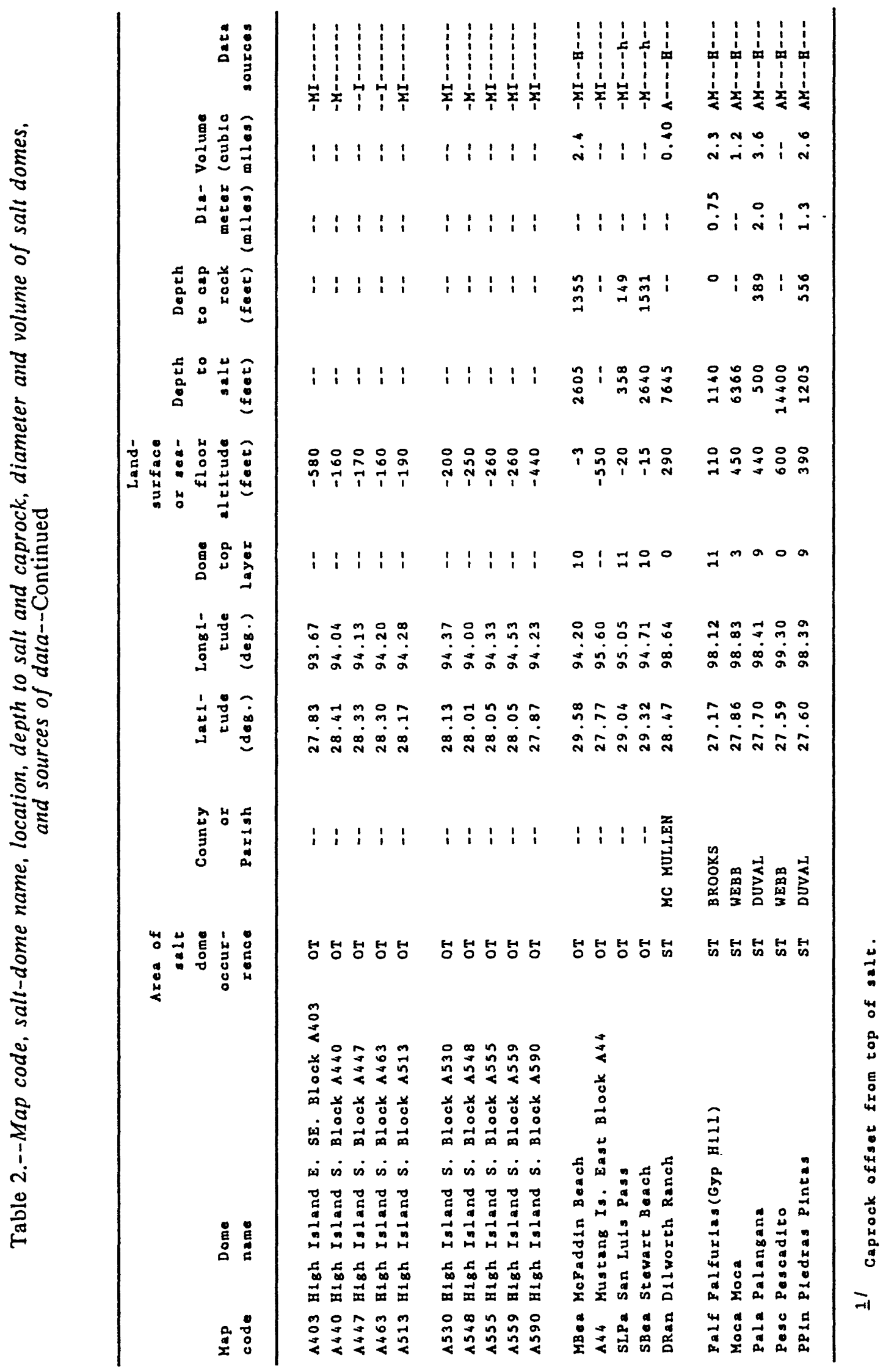

